\title{
PETROLOGY AND GEOCHEMISTRY OF THE GRANITOID ROCKS OF THE JOHANNESBURG DOME, CENTRAL KAAPVAAL CRATON, SOUTH AFRICA
}

\author{
D.M. VAN TONDER \\ Department of Geology, University of Pretoria, South Africa. \\ Council for Geoscience, Private Bag X112, Pretoria, 0001, South Africa \\ e-mail: dvtonder@geoscience.org.za
}

\author{
H. MOURI \\ Department of Geology, University of Johannesburg, South Africa. \\ e-mail: hmouri@uj.ac.za
}

C 2010 September Geological Society of South Africa

\begin{abstract}
The Johannesburg Dome (JD) in the central Kaapvaal Craton (KC) is dominated by granitoid rocks of the tonalite-trondhjemitegranodiorite (TTG) series. Based on modal analysis as well as a major and trace element investigation the JD granitoids could be subdivided into three main suites, i.e. a Tonalitic gneiss suite (TG) around the southern boundary, a Granodiorite to Adamellite Gneiss suite (GAG) across the northern part, and a Granodiorite/adamellite to Granodiorite suite (GG) occurring between the TG and GAG suites. These rocks are dominantly I-type and peraluminous with the tonalites (TG and partly the GAG suites) falling in the metaluminous field. TTGs of the JD are high-K calc-alkaline to calc-alkaline and are dominantly high silica rocks $\left(\sim 70\right.$ weight \%), aluminous $\left(\mathrm{Al}_{2} \mathrm{O}_{3}>15 \mathrm{wt} \%\right)$ with low $\mathrm{Yb}(<1 \mathrm{ppm})$, high $\mathrm{La} / \mathrm{Yb}$ ratios $(>30)$, high $\mathrm{Na}_{2} \mathrm{O} / \mathrm{K}_{2} \mathrm{O}(>1)$, and have $\mathrm{Na} 2 \mathrm{O}$ contents of between $3 \mathrm{wt} \%$ and $5 \mathrm{wt} \%$, comparable to that of the average TTG. The JD tonalities (TG suite) have higher $\mathrm{Al}_{2} \mathrm{O}_{3}, \mathrm{Sr}$, $\mathrm{Na}_{2} \mathrm{O} / \mathrm{K}_{2} \mathrm{O}, \mathrm{Mg} \#, \mathrm{Ni}, \mathrm{Cr}$ and LILE contents compared to the more calc-alkaline granitoids (GG suite and trondhjemites of the GAG suite), which are typically richer in HREE (lower REE fractionation), Y and show a negative Sr and Eu anomaly. Other characteristic features of the JD TTG's include HFSE depletion and distinct enrichment of fluid sensitive elements such as Pb. The strongly fractionated REE pattern, high $(\mathrm{La} / \mathrm{Yb})_{\mathrm{N}}$ ratio and depletion in HREE $(\mathrm{Yb})$ of the JD TTGs are characteristics shared with modern adakites. The TG suite most probably formed through melting of a subducted oceanic slab with the melt interacting with mantle peridotite during its accent through a thin mantle wedge. The remaining JD granitoids (GAG and GG) most probably formed through the remelting of a TTG protolith, which has a subducted slab and mantle wedge signature (similar to the TG suite),
\end{abstract}

\section{Introduction}

Archaean cratons typically consist of three main rock associations, i.e. greenstone belts, tonalite-trondhjemitegranodiorite gneisses (termed "TTG suite" by Jahn et al., 1981) and calc-alkaline K-rich granitoids (Windley, 1995 and Moyen et al., 2003). Based on studies of the Barberton Mountain Land, De Wit (1998) referred to the latter as granodioritic-granitic-monzogranitic (GGM) suites. While TTG associations are the main components of the Archaean continental crust generated between 4.0 and $2.5 \mathrm{Ga}$ (Jahn et al., 1981; Smithies et al., 2003), the calc-alkaline GGM or high K-granodiorite suites dominate large parts of Archaean cratons formed between 2.8 and $2.5 \mathrm{Ga}$. There is a general agreement that the GGM suites form at mid to lower crustal levels through partial melting of the preexisting TTG crust and sediments (De Wit, 1998 and references therein).

Although information fundamental to understanding Archaean tectonics and crustal evolution has been steadily forthcoming over the last decade, the origin of TTG magmas is still widely debated. Suggestions on the origin of TTG magmas vary from fractional crystallisation of basaltic melts (Arth et al., 1978), through partial melting of mantle rocks (Moorbath, 1975), to partial melting of pre-existing tonalites (Johnston and Wyllie,
1988). However, the most widely accepted mechanism is that of partial melting of hydrous metabasaltic rocks, i.e. greenstones, amphibolites and eclogites, under a variety of fluid pressures in a variety of tectonic settings (Martin, 1987; Wyllie, 1997; Condie, 2005). These petrogenetic models are largely based on the fact that the chondrite-normalised REE patterns of TTG rocks are typically HREE-depleted and LREE-enriched. Growing support for analogies drawn between present-day plate tectonics and Archaean geotectonic processes has lead to the re-evaluation of Archaean terrains world-wide (De Wit et al., 1992; Moyen et al., 2003; Blewett, 2002; Smithies et al., 2003; Poujol et al., 2003). Analogies between Archaean TTG suites and modern adakites strongly suggest that modern-style subduction processes, including interaction between slab-derived components and the mantle wedge, occurred as far back as 3.3 Ga. (Condie, 1981; Martin, 1999; Martin et al., 2005).

TTG suites are generally subdivided into a TTG series and a high-Mg diorite (sanukitoid) series (Smithies and Champion, 2000). The high-Mg diorite series was first recognised by Shirey and Hanson (1984) as a Late Archaean suite of felsic intrusives and volcanic rocks from the Superior Province. The major element 


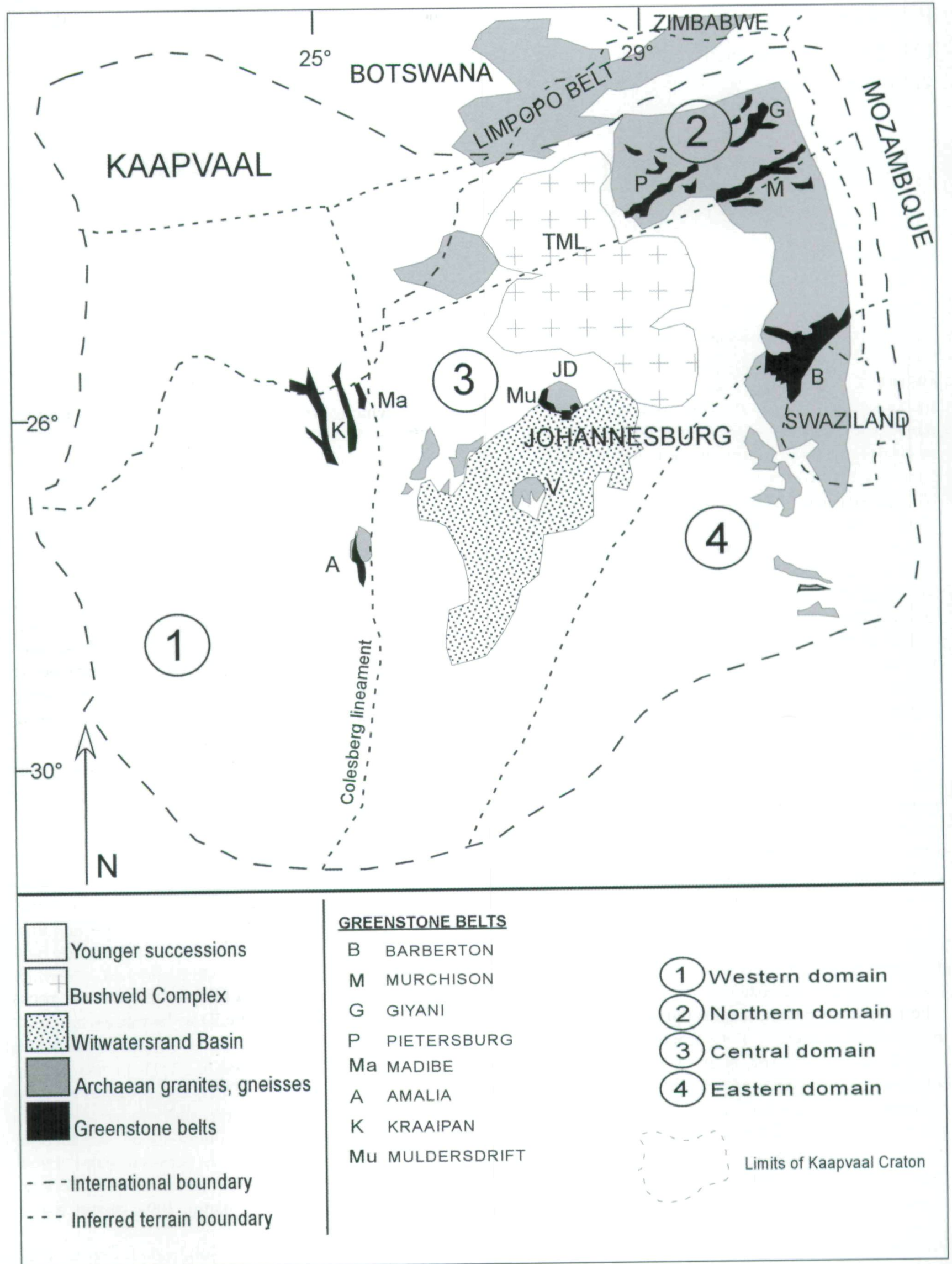

Figure 1. Locality map showing the position of the Johannesburg Dome (JD) relative to the outline of the Kaapvaal Craton and main geological components. JD is situated in the central domain (3) along with the Vredefort Dome (V). (Modified after Eglington and Armstrong, 2004). 
geochemistry of the high-Mg diorite series resembled that of a Miocene high- $\mathrm{Mg}$ andesite (sanukite) from Japan and was therefore referred to as "Archaean sanukitoids" (Shirey and Hanson, 1984). Subsequently similar suites of rock was recognized in other TTG occurrences (such as the central Pilbara Craton) and are now generally regarded as a minor, widespread component of most Late Archaean terranes that postdates the dominant TTG series (Smithies and Champion, 1999; Smithies, 2000; Smithies et al., 2003; Martin et al., 2005). These rocks, which resemble modern high magnesian andesites (HMA), may constitute up to $25 \%$ of Archarean plutonic rocks (Evans and Hanson, 1997). Sanukitoid suite composition ranges from dioritic to granodioritic (tonalite is subordinate). More recently a rock type, which shares several characteristics with sanukitoids, the Closepet-type granite, were recognised from South India (Moyen et al,, 2001), China and South Africa (Limpopo) (Barton et al., 1992). Closepet-type granite differs from sanukitoid in having higher $\mathrm{K}_{2} \mathrm{O} / \mathrm{Na}_{2} \mathrm{O}$ ratios $(<1)$ and being relatively enriched in $\mathrm{Ti}$, $\mathrm{Nb}$ and $\mathrm{Zr}$. In contrast to TTG, sanukitoid and Closepettype granite follow a classical calc-alkaline trend in the K-Na-Ca triangle (Martin, 2005). Furthermore the high $\mathrm{MgO}, \mathrm{Mg}^{\#}, \mathrm{Cr}, \mathrm{Ni}$, and $\mathrm{K}_{2} \mathrm{O}$ distinguish sanukitoid and Closepet-type granite from TTGs (Martin et al., 2005).

Previous gechemical work recorded on the JD gtranitoids is very limited with one dataset of major and some trace element analyses available for the entire JD (Anhauesser, 1973) and the occasional RE element analyses of isolated areas on the western boundary (Anhauesser, 1999). In this paper an attempt is made, using a complete set of petrographic, mineral chemistry, major-, trace- and RE element data, to identify the subcomponents of the Archaean granitoid rocks of the Johannesburg Dome (JD), to classify them within the current framework of understanding of the TTG suites and to propose processes involved in the petrogenesis of these granitoids.

\section{Geological background \\ The Kaapvaal Craton}

The Kaapvaal Craton occupies the south central interior of southern Africa and is one of only a few areas in the world where pristine mid-Archaean rocks have been preserved. The Craton is bound by the $\sim 1.2$ to $\sim 1.0 \mathrm{Ga}$ Proterozoic Namaqua-Natal metamorphic province to the south, by the $\sim 1.8 \mathrm{Ga}$ Kheis belt to the west and by the Limpopo belt and the Archean Zimbabwe craton to the north (Hartnady et al., 1985; Cornell et al., 1998; Kusky, 1998) (Figure 1).

Geochronological and tectonic studies suggested that the formation of Kaapvaal Craton, through subduction and amalgamation of smaller crustal fragments, took place in two distinct periods (de Wit, 1992; Smithies and Champion, 2000; Bedard et al., 2003). The initial shieldforming stage, which spanned from $\sim 3.7$ to $\sim 3.1 \mathrm{Ga}$, was followed by a stage of accretion of continental fragments and stabilization between $\sim 3.1 \mathrm{Ga}$ and $\sim 2.6 \mathrm{Ga}$ (De Wit et al., 1992; Thomas et al., 1993; Lowe, 1994; Anhauesser, 1999; Poujol et al., 2003; Eglington and Armstrong, 2004). These smaller crustal fragments include the oldest $\sim 3.5 \mathrm{Ga}$ eastern domain (Barberton Mountain Land, BML); a $\sim 3.0$ Ga northern domain (Murchison-, MGB, Giyani-, GGB, and Pietersburg, PGB, Greenstone Belts; a $\sim 3.2$ to $\sim 3.0$ Ga central domain (granitoid domes such as the Johannesburg Dome (JD), Rand anticline and Vredefort Dome); and the western and youngest $\sim 3.0$ to $\sim 2.7$ Ga domain (Kraaipan-, KGB, Amalia-, AGB, and Madibe, MaGB, Greenstone Belts) (de Wit et al., 1992; Thomas et al., 1993; Brandl and de Wit, 1997; Poujol et al., 1999; Eglington and Armstrong, 2004; Poujol et al., 2003) (Figure 1). The Colesberg and Thabazimbi-Murchinson lineaments have been considered to represent suture zones along which younger domains were accreted to form the Kaapvaal Craton (Eglington and Armstrong, 2004).

\section{The Jobannesburg Dome}

Of all the Archaean rock occurrences in the central Kaapvaal Craton, those of the Johannesburg Dome (JD), a $700 \mathrm{~km}^{2}$-sized oval-shaped window of Archaean mafic to ultramafic units intruded by tonalite, trondhjemites and granodiorite, is probably best exposed. Consequently, this granitoid-greenstone terrain is well suited for -studies of Archaean crustal evolution of central Kaapvaal Craton (Figure 2).

Although the only nomenclature presently accepted by the South African Committee for Stratigraphy (SACS, 1980) refers to this window of Archaean rocks as the "Halfway House Dome" the term Johannesburg Dome has been widely used in recent publications and is therefore sustained in this publication.

The oldest recognisable rocks of the JD are described as a variety of mafic and ultramafic rocks with komatiitic to high-magnesian basaltic and tholeiitic affinities similar to those seen in the BML and believed to have formed in an Archaean oceanic or volcanic arc-like geotectonic setting (Viljoen and Viljoen, 1969; Anhauesser, 1973; $1977 ; 1978 ; 1992 ; 1999)$. These mafic to ultramafic rocks have limited exposures in the JD with larger occurrences present mainly around its western, southwestern and southeastern margins, i.e. the Roodekrans, Muldersdrift and Zandspruit complexes (Figure 2). A unit of poorly exposed metavolcanics, containing amygdales, spherulites and locally developed pillow structures, separates the Roodekrans and Muldersdrift Complexes (Anhaeusser, 1977; 1978). Smaller isolated bodies (centimeter- to meter-scaled) are found scattered across the JD, in some instances aligned parallel to the gneissosity (Anhauesser, 1973; 1977; 1978). Recent work by Anhauesser (2004), however, suggests that the maficultramafic assemblages on the JD represent a suture or oceanic crustal collisional zone between two colliding crustal blocks, similar to that found in Phanerozoic ophiolite complexes. This assumption is based on the 


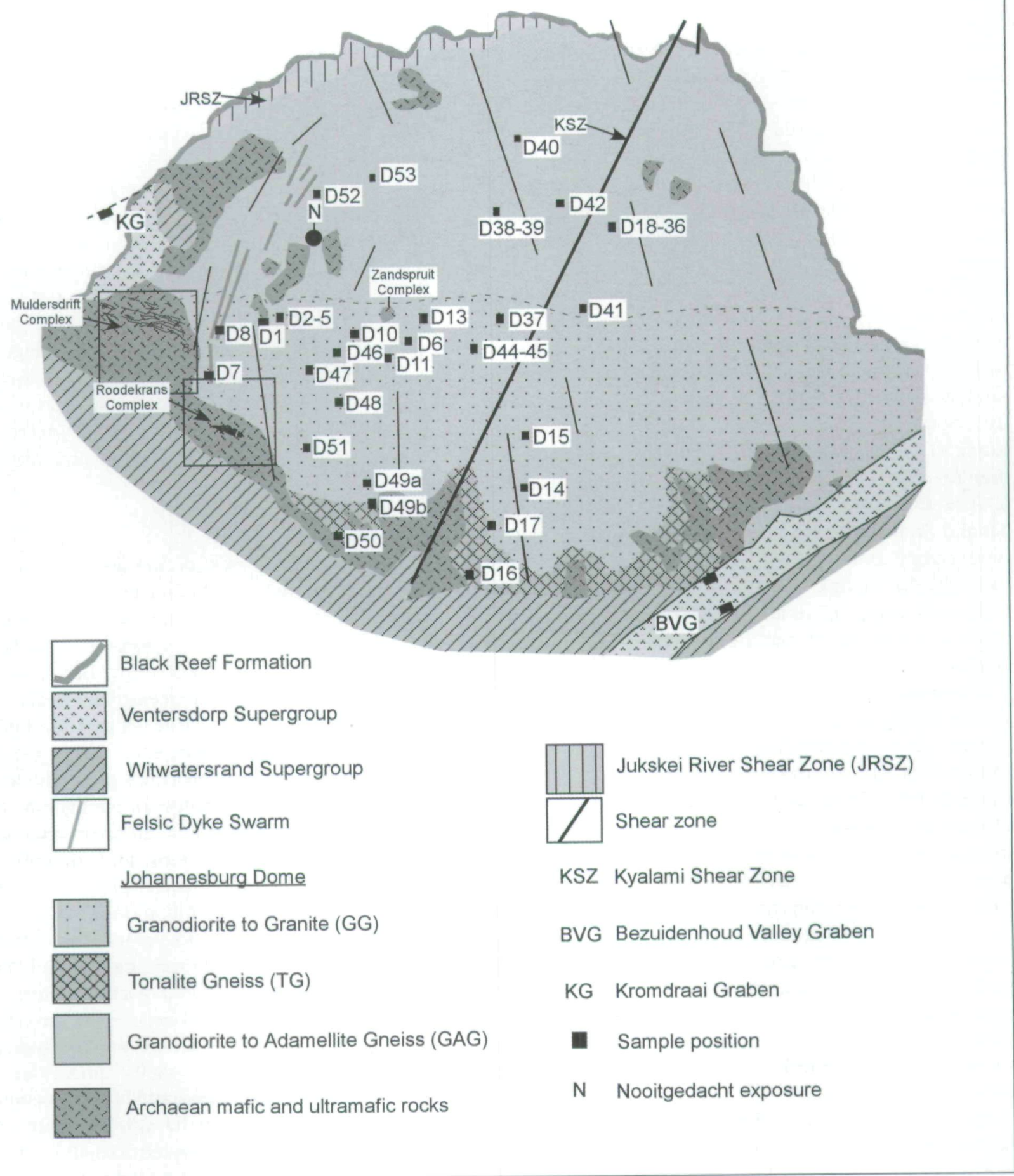

Figure 2. Simplified geology map of the JD (not to scale).

fact that the JD mafic-ultramafic assemblages lack evidence of other lithologies akin to greenstone complexes. Through reassessment of the maficultramafic assemblages Anhauesser (op. cit.) showed these rocks to be closely linked to upper mantle or oceanic crust.

Supracrustals unconformably overlying the Archaean lithologies dip radially away from the central dome (Figure 2). The southern boundary of the JD is marked by rocks of the Witwatersrand and Ventersdorp Supergroups whereas the northern boundary of the JD is constituted by quartzites and shales of the Black Reef Formation, which occurs at the base of the Transvaal Supergroup (Anhaeusser, 1973). Although a sedimentary contact between the Witwatersrand Supergroup and the granitoids of the JD has been established by earlier studies (Corstophine, 1908), Hilliard (1994) as well as Roering (1986) showed the contact is highly sheared. 
Deformation in the JD granitoids is evidenced by the gneissic foliation as well as strike-slip shear movement zones developed mainly in two prominent cross cutting directions, i.e. northwest to southeast and northeast to southwest (Hilliard, 1994) (Figure 2).

Hilliard (1994) proposed the shearing seen in the JD granitoids pre-dates the deposition of the Black Reef Formation, with later re-activation as brittle faults displacing the Transvaal Supergroup in post-Black Reef times (Hilliard and McCourt, 1995). The latter deformation pre-dates the JD doming event which is believed to have occurred after the Vredefort event (McCarthy et al., 1986; Hilliard, 1994). The more prominent deformation is, however, confined to the supracrustals (McCarthy et al., 1982; Stranistreet and McCarthy, 1986; Stranistreet and McCarthy, 1990; McCarthy et al., 1990; Charlesworth and McCarthy, 1990).

\section{Geochronology and field relationships}

The central domain (JD, Rand anticline and Vredefort Dome) of the KC was mainly active between $~ 3.2$ to 3.0 Ga during the craton accretion and stabilisation period (3100 Ma to $2600 \mathrm{Ma}$ ) (De Wit et al., 1992; Anhauesser, 1999; Thomas et al., 1993). Barton et al. (1999) suggested that granitoid magmatism of this age was widespread as JD granitoid magmatism is coeval with magmatism in the Barberton area. Poujol et al., (2003) highlighted three main magmatic events over the central part of the Kaapvaal Craton. These events occurred at $\sim 3.2$ to $\sim 3.18 \mathrm{Ga}, \sim 3.12$ to $\sim 3.08 \mathrm{Ga}$ and $\sim 2.73$ to $2.71 \mathrm{Ga}$ respectively. Barton et al. (1999) also showed neither the $\sim 2.025 \mathrm{Ga}$ Vredefort event (Koma et al., 1996; Gibson et al., 1999) nor the $\sim 2.06 \mathrm{Ga}$ intrusion of the Bushveld Complex (Kruger et al., 1987) had a significant influence on the formation of the JD granitoids.

In recent years the main focus of studies on the JD granitoids was the geochronology of the various granitoids, the most important findings from these studies has been summarized in Table 1. Barton et al. (1999) also proposed that granitoids of the JD were genetically related and were derived from a $\sim 3.35$ to $\sim 3.3 \mathrm{Ga}$ year old source. The most recent (post-1999) age determinations, utilizing the ${ }^{207} \mathrm{~Pb} /{ }^{206} \mathrm{~Pb}$ single zircon technique, showed two key periods of magmatism across the JD. The oldest phase $3340 \pm$ $3 \mathrm{Ma}$; Poujol and Anhaeusser, 2001) is tonalitic to adamellite and granodiorite gneiss around the northern half of the JD and related tonalitic gneiss (3201 $\pm 5 \mathrm{Ma}$; (op cit)) around the southern edge of the JD. This phase was followed by a second period of magmatism manifested as a medium-grained homogeneous granodiorite to adamellite ( $3121 \pm 5 \mathrm{Ma}$; (op cit)) across the southeastern part of the JD and a porphyritic granodiorite to adamellite and granite $(3114 \pm 2 \mathrm{Ma}$; (op cit)), occurring generally in the southwestern part of the JD (Table 2). Barton et al. (1999) also showed through Sm-Nd isotopic analyses that the leucosome of the migmatite (northern JD) is possibly cogenetic with the youngest granodioritic to granitic magma. These ages correspond to Poujol et al.'s (2003) first $(\sim 3.2$ to $3.18 \mathrm{Ga})$ and second $(\sim 3.12$ to $3.08 \mathrm{Ga})$ phase events for the central Kaapvaal Craton.

This paper proposes that the JD is comprised of three main suites based on the geochronological data and field relationships. The extent of each suite is indicated on the simplified geological map (Figure 2). The three suites, broadly similar to those proposed by Robb et al. (2008) are:

1. Granodiorite- to Adamellite Gneiss suite (GAG) with local development of tonalite and trondhjemite gneiss, i.e. probably the $\sim 3.34 \mathrm{Ga}$ rocks of the same composition of Poujol and Anhaeusser (2001) (Lanseria Gneiss, Robb et a.1., 2008) occurring over much of the northern JD; and

2. Tonalite Gneiss suite (TG) i.e. the $\sim 3200 \mathrm{Ma}$ tonanlitic gneiss of Poujol and Anhaeusser (2001) (Linden Gneiss, Robb et a.l., 2008) occurring around the southern edge of the JD;

3. Granodiorite-to-granite suite (GG) occurring between the TG suite in the south and the GAG suite in the north, i.e. the $\sim 3.1$ Ga rocks of Poujol and Anhaeusser (2001) (Bryanstone, Honeydew and Victory Park Granodiorite, Robb et al., 2008).

Unfortunately, due to generally poor rock exposure, the contacts between the three main suites are largely obscured. The field relationship of the three main suites and locally occurring porphyritic, coarse-grained pinkish-red and dioritic marginal varieties could only be seen at isolated outcrops such as the Nooitgedacht outcrop in the northwest. However, the significance of the observed field relationships are uncertain as these could not be extrapolated for the entire JD The relative age relations suggested from previous work could not be tested in the field.

\section{Granodiorite-to-Adamellite Gneiss suite ( $G A G)$}

This suite consists mostly of granodioritic to adamellitic banded gneiss with tonalitic/trondhjemitic gneiss "patches" (Figure 3a). "Patches" $\left(<1 \mathrm{~m}^{2}\right.$ sized areas) are gradational into granodiorite and/or adamellite and form a subordinate component not developed throughout the GAG suite. The GAG suite is strongly foliated consisting of alternating leucocratic and melanocratic bands (2 to $20 \mathrm{~cm}$ thick) with widespread occurrences of centi- to decimeter-sized, irregularly-shaped ultramafic xenoliths. In many cases the foliation and banding have been intricately folded suggesting that variable stress fields have influenced the formation of these rocks. The foliation in unfolded rocks has an average strike of $120^{\circ}$ to $130^{\circ}$, which corresponds to that in the TG suite. The dominant mineral assemblage in the GAG gneiss is medium-grained quartz, K-feldspar, plagioclase and biotite. 
Table 1. Summary of geochronological data for the HHD granitoids.

\begin{tabular}{|c|c|c|c|c|c|c|c|}
\hline Locality & $\begin{array}{l}\text { Age } \\
(\mathrm{Ma})\end{array}$ & Error & $\begin{array}{r}\text { classifica } \\
\text { (this st } \\
\end{array}$ & $\begin{array}{l}\text { Rock } \\
\text { ation } \\
\text { tudy) }\end{array}$ & Method & Year & Reference \\
\hline North-western quadrant & 2087 & \pm 42 & $\begin{array}{l}\text { Leucosome of } \\
\text { migmatitic gneiss }\end{array}$ & GAG & Rb-Sr whole rock & 1999 & Barton et al. \\
\hline South-central (Witkoppen) & 2120 & \pm 10 & Granite & GG & Rb-Sr biotite & 1961 & Allsopp \\
\hline North-western quadrant & 2188 & \pm 44 & $\begin{array}{l}\text { Leucosome of } \\
\text { migmatitic gneiss }\end{array}$ & GAG & $\mathrm{Rb}-\mathrm{Sr}$ whole rock & 1999 & Barton et al. \\
\hline South-central & $\begin{array}{ll}2 & 202 \\
2 & 117 \\
2 & 240 \\
2 & 110 \\
2 & 158 \\
\end{array}$ & $\begin{array}{l} \pm 56 \\
\pm 47 \\
\pm 53 \\
\pm 45 \\
\pm 47 \\
\end{array}$ & Granodiorite and granite & GG & $\begin{array}{l}\text { Rb-Sr biotite } \\
\text { whole rock }\end{array}$ & 1999 & Barton et al. \\
\hline $\begin{array}{l}\text { South-central } \\
\text { (Waterval 5IR) } \\
\end{array}$ & 2236 & \pm 55 & Xenolith in granodiorite & GAG & $\begin{array}{l}{ }^{207} \mathrm{~Pb} /{ }^{206} \mathrm{~Pb} \\
\text { composite zircon }\end{array}$ & 1979 & $\begin{array}{l}\text { Burger } \\
\text { and Walraven }\end{array}$ \\
\hline South Central & 2261 & \pm 80 & & GG & & 1999 & Barton et al. \\
\hline $\begin{array}{l}\text { South-central } \\
\text { (Halfway House) }\end{array}$ & 2310 & \pm 40 & Granite & GG & Rb-Sr biotite & 1961 & Allsopp \\
\hline Southern rim & 2321 & \pm 23 & Tonalite & TG & Rb-Sr biotite & 1999 & Barton et al. \\
\hline Southern rim & 2385 & \pm 127 & Tonalite & TG & $\mathrm{Rb}-\mathrm{Sr}$ whole rock & 1999 & Barton et al. \\
\hline South-central (Lone Hill) & 2585 & \pm 65 & $\begin{array}{l}\text { Homogeneous } \\
\text { granodiorite }\end{array}$ & GG & $\begin{array}{l}{ }^{207} \mathrm{~Pb} /{ }^{206} \mathrm{~Pb} \\
\text { composite zircon }\end{array}$ & 1979 & $\begin{array}{l}\text { Burger } \\
\text { and Walraven }\end{array}$ \\
\hline North-eastern quadrant & $\begin{array}{ll}2614 \\
2430 \\
\end{array}$ & $\begin{array}{l} \pm 53 \\
\pm 50 \\
\end{array}$ & $\begin{array}{l}\text { Leucosome of migmatitic } \\
\text { gneiss }\end{array}$ & GAG & $\begin{array}{l}\text { Rb-Sr biotite } \\
\text { whole rock }\end{array}$ & 1999 & Barton et al. \\
\hline Southern rim & 3001 & $\begin{array}{l}+132 / \\
-146 \\
\end{array}$ & Tonalite & TG & $\mathrm{Pb}$ whole rock & 1999 & Barton et al. \\
\hline South-central & 3081 & \pm 33 & Granodiorite and granite & GG & $\begin{array}{l}\text { Average } \mathrm{Rb}-\mathrm{Sr} \\
\text { whole rock }\end{array}$ & 1999 & Barton et al. \\
\hline South-central & 3112 & \pm 14 & Granodiorite and granite & GG & $\begin{array}{l}{ }^{207} \mathrm{~Pb} /{ }^{206} \mathrm{~Pb} \\
\text { whole rock }\end{array}$ & 1999 & Barton et al. \\
\hline North-western quadrant & 3135 & \pm 52 & $\begin{array}{l}\text { Leucosome of migmatitic } \\
\text { gneiss }\end{array}$ & GAG & $\mathrm{Rb}-\mathrm{Sr}$ whole rock & 1999 & Barton et al. \\
\hline Southern rim & 3170 & \pm 34 & Tonalite gneiss & TG & U-Pb multiple zircon & 1982 & $\begin{array}{l}\text { Anhauesser } \\
\text { and Burger }\end{array}$ \\
\hline South-central & $\begin{array}{l}3200 \\
3132 \\
\end{array}$ & $\begin{array}{l} \pm 65 \\
\pm 64 \\
\end{array}$ & Granite & GG & Rb-Sr whole rock & $\begin{array}{l}1961 \\
1964 \\
\end{array}$ & $\begin{array}{l}\text { Allsopp } \\
\text { Allsopp } \\
\end{array}$ \\
\hline South-central & 3158 & \pm 179 & Granodiorite and granite & GG & $\mathrm{Rb}-\mathrm{Sr}$ whole rock & 1999 & Barton et al. \\
\hline Southern rim & 2947 & \pm 57 & $\begin{array}{l}\text { Medium- to coarse-grained } \\
\text { homogeneous granodiorite }\end{array}$ & GG & ${ }^{207} \mathrm{~Pb} / 206 \mathrm{~Pb}$ zircon & 2001 & $\begin{array}{l}\text { Poujol } \\
\text { and Anhauesser }\end{array}$ \\
\hline $\begin{array}{l}\text { North-western quadrant } \\
\text { (Nooitgedacht) }\end{array}$ & 2997 & \pm 7 & Trondhjemite gneiss & GAG & ${ }^{207} \mathrm{~Pb} /{ }^{206} \mathrm{~Pb}$ zircon & 2001 & $\begin{array}{l}\text { Poujol } \\
\text { and Anhauesser }\end{array}$ \\
\hline South-central & 3101 & \pm 5 & Granodiorite and granite & GG & ${ }^{207} \mathrm{~Pb} / 206 \mathrm{~Pb}$ zircon & 2001 & $\begin{array}{l}\text { Poujol } \\
\text { and Anhauesser }\end{array}$ \\
\hline South central & 3121 & \pm 5 & $\begin{array}{l}\text { Medium-grained grey } \\
\text { granodiorite }\end{array}$ & GG & ${ }^{207} \mathrm{~Pb} /{ }^{206} \mathrm{~Pb}$ zircon & 2001 & $\begin{array}{l}\text { Poujol } \\
\text { and Anhauesser }\end{array}$ \\
\hline South-western quadrant & 3114 & \pm 2 & Porphyritic granodiorite & GG & ${ }^{207} \mathrm{~Pb} /{ }^{206} \mathrm{~Pb}$ zircon & 2001 & $\begin{array}{l}\text { Poujol } \\
\text { and Anheasusser }\end{array}$ \\
\hline Southern rim & 3199.9 & \pm 2 & Tonalite gneiss & TG & ${ }^{207} \mathrm{~Pb} /{ }^{206} \mathrm{~Pb}$ zircon & 2001 & $\begin{array}{l}\text { Poujol } \\
\text { and Anhauesser }\end{array}$ \\
\hline North-western quadrant & 3213 & \pm 10 & Trondhjemite gneiss & GAG & ${ }^{207} \mathrm{~Pb} /{ }^{206} \mathrm{~Pb}$ zircon & 2001 & $\begin{array}{l}\text { Poujol } \\
\text { and Anhauesser }\end{array}$ \\
\hline South-western quadrant & 3227 & \pm 21 & $\begin{array}{l}\text { Medium-grained grey } \\
\text { granodiorite }\end{array}$ & GG & ${ }^{207} \mathrm{~Pb} /{ }^{206} \mathrm{~Pb}$ zircon & 2001 & $\begin{array}{l}\text { Poujol and } \\
\text { and Anhauesser }\end{array}$ \\
\hline North-western quadrant & 3340 & \pm 3.3 & Trondhjemite gneiss & GAG & ${ }^{207} \mathrm{~Pb} /{ }^{206} \mathrm{~Pb}$ zircon & 2001 & $\begin{array}{l}\text { Poujol } \\
\text { Anhauesser }\end{array}$ \\
\hline
\end{tabular}




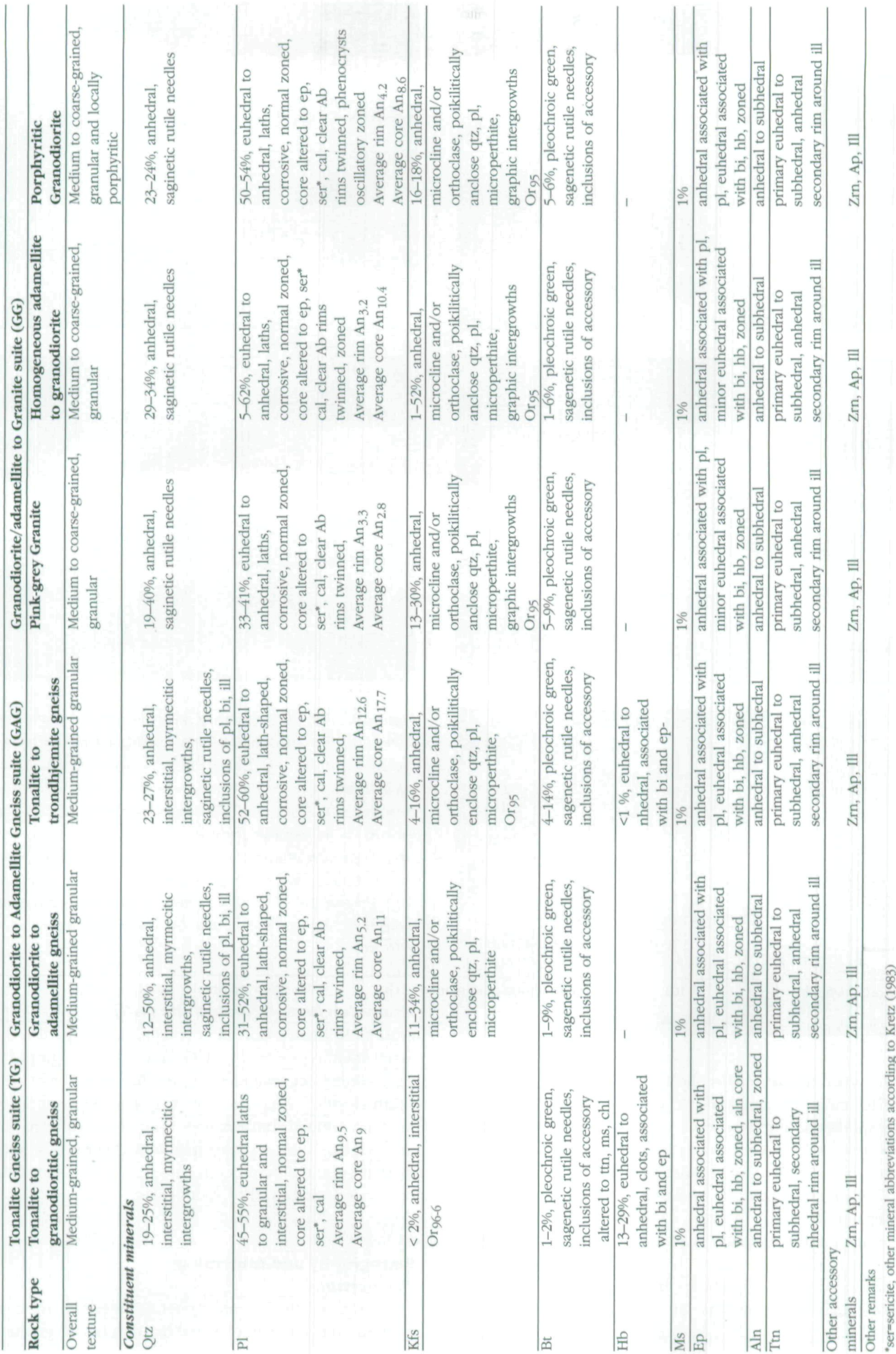



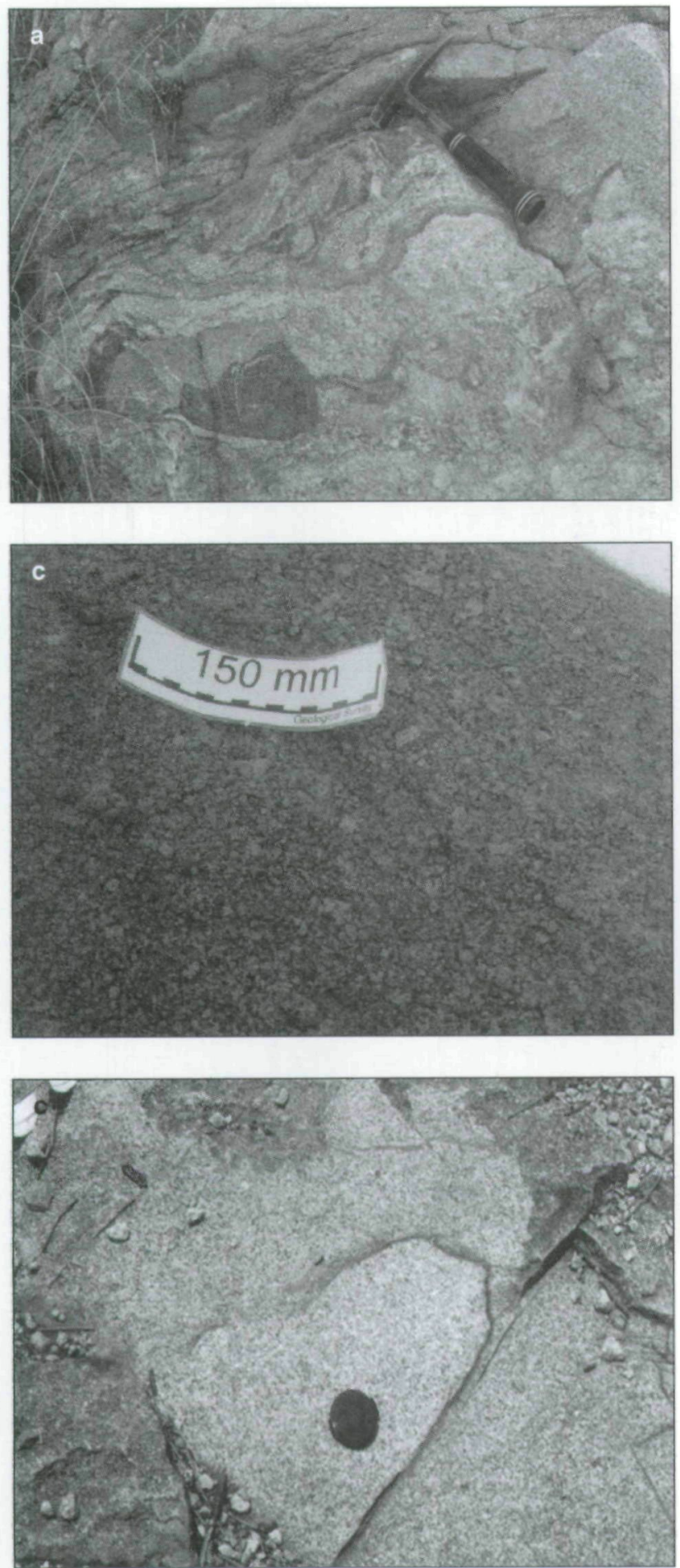

\section{Tonalite Gneiss suite (TG)}

This suite of medium to coarse-grained tonalite to granodiorite gneiss occurs as a homogeneous unit in contact with Archaean mafic and ultramafic remnants around the southern edge of the JD (Figure 2). The tonalite gneiss is made-up of quartz, plagioclase, amphibole and biotite, $\pm \mathrm{K}$-feldspar and accessory minerals such as apatite, zircon and alanite. The gneissic fabric of the rock (Figure 3b) is defined by the preferred orientation of amphibole and biotite. Smaller mafic to ultramafic xenoliths are aligned parallel to the foliation.
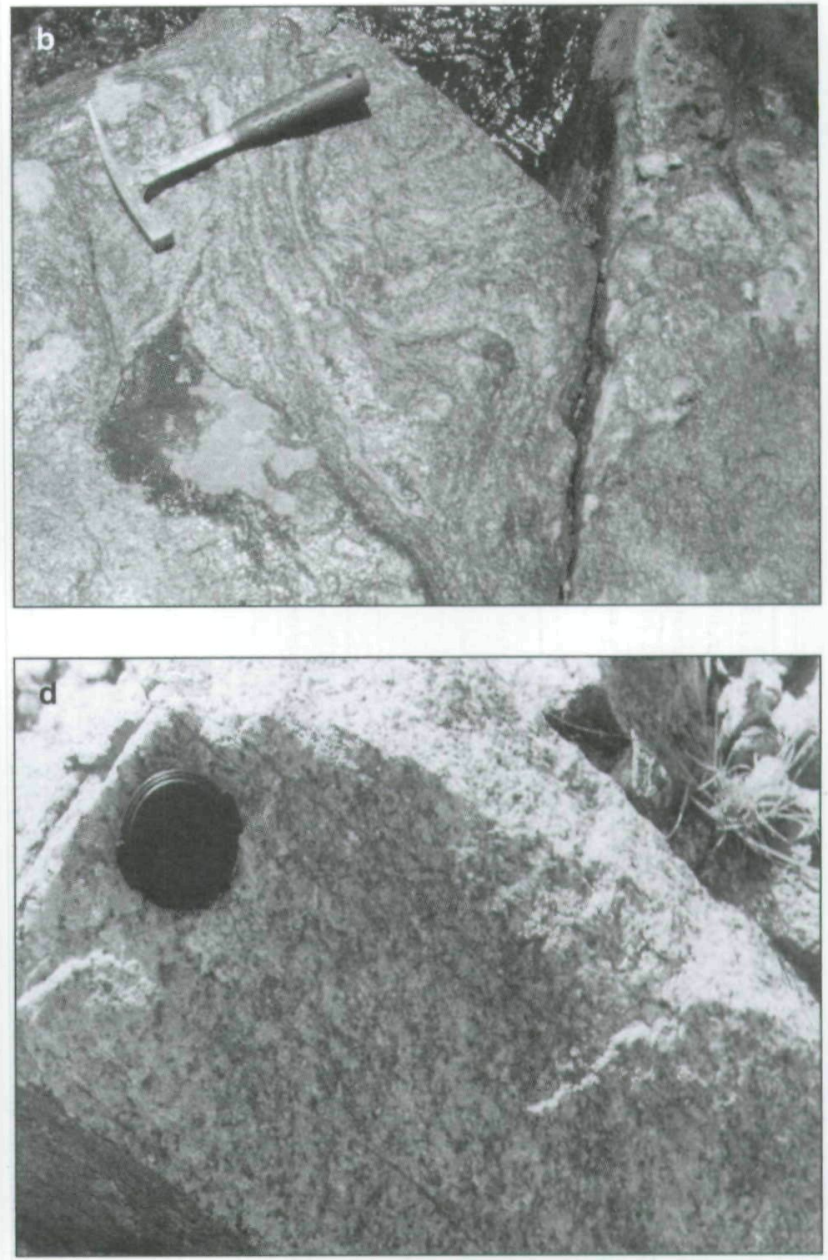

Figure 3. (a) Photograph of a typical foliated granodiorite/ adamellite gneiss from the GAG suite showing amphibolite to diorite inclusions (arrow) (b) Photograph of a typical tonalitic gneiss of the TG suite. Note the ultramafic xenolith (arrow), aligned with foliation. (c) Photograph of a typical porphyritic granodiorite of the GG suite showing feldspar phenocrysts of up to $2 \mathrm{~cm}$. (d) Photograph of a typical medium to coarse-grained, pinkishgrey granite of the $G G$ suite (Lens cap diameter $=50 \mathrm{~mm}$ ) (e) Photograph of a typical medium-grained, homogeneous adamellite/ granodiorite of the GG suite (Lens cap diameter $=50 \mathrm{~mm}$ )

\section{Granodiorite-to-Granite suite (GG)}

From field observations it is possible to distinguish three main rock types in the GG suite, i.e. 1) porphyritic granodiorite occurring locally, but not exclusively, in the south-western quadrant of the JD (Figure 3c), 2) medium-grained pinkish-grey granite developed over most of the south-western quadrant (Figure 3d), and 3) medium-grained homogeneous adamellite/granodiorite developed across the south-eastern part of the JD (Figure 3e).

\section{Petrography and mineralogy Petrography}

The rocks of the JD are generally medium to coarse grained, and consists of variable amounts of granularly 


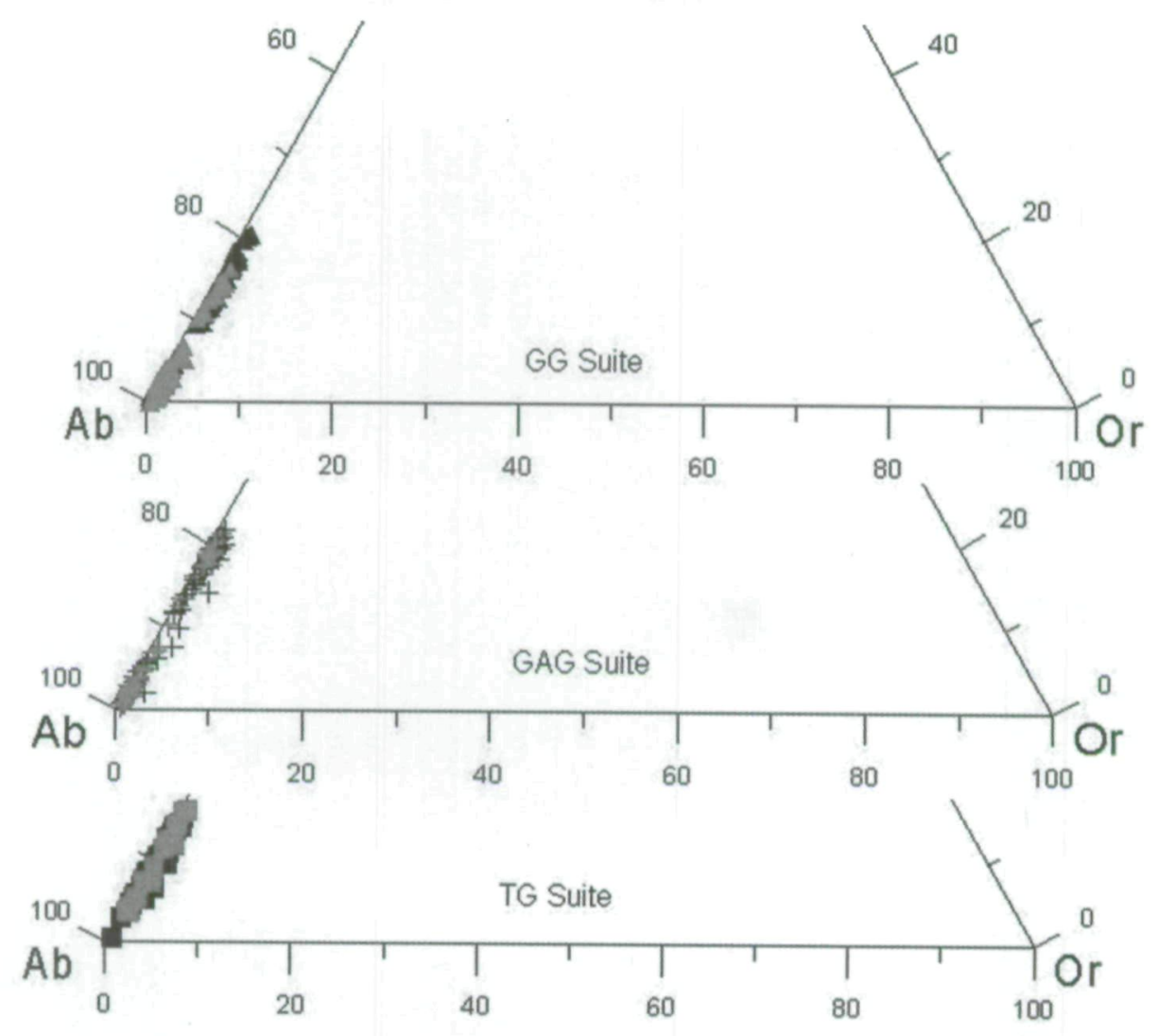

Figure 4. An-Ab-Or diagram for the electron microprobe data showing the plagioclase rim (red) and core (black) compositions for JD suites.

arranged plagioclase, quartz, K-feldspar, \pm hornblende and biotite with accessory minerals including epidote, apatite, zircon, muscovite, allanite, and titanite. Table 2 summarizes the major textural and mineralogical features of the various rock types of the JD. Modal mineral composition of the various granitoid rocks of the JD is reported in Table 2. Mineral abbreviations as recommended by Kretz (1983) are used throughout. It is of note that the TG suite of the JD is comparable to that of typical Achaean TTG (after Clarke, 1992) for all minerals except biotite and hornblende. The TTG is depleted in hornblende $( \pm 0-5 \%)$ and enriched in biotite $(5-10 \%)$ relative to the TG rocks.

\section{Mineral morphology and chemistry}

Plagioclase ranges from oligoclase to albite (as determined by electron microprobe) and occurs as lathshaped to granular crystals ranging between 0.5 and $4.5 \mathrm{~mm}$ in size. Plagioclase in the TG suite is extensively serisitized and saussuritized. The majority of plagioclase grains in the GAG and GG suites show zoning with cores altered to epidote, sericite and calcite (optically clouded), followed by alternating moderately altered to alteration-free (optically clear) zones. Distinctly alteration-free rims are developed exclusively on the boundaries between plagioclase and K-feldspar and absent where quartz is in contact with plagioclase or $\mathrm{K}$-feldspar in the GAG and GG suites. It is, however, important to point out that there is a clear distinction between normal oscillatory zoning (formed above the solidus), generally observed in plagioclase phenocrysts, and these rims which are sub-subsolidus in origin.

Compositions of plagioclase from the three main JD suites are plotted on an An-Ab-Or diagram (Figure 4). The An-content of plagioclase increases slightly from the TG suite to the GG and GAG suites (Table 3). Both core and rim datasets are weakly bimodal with the cores mainly $\mathrm{An}_{8}-\mathrm{An}_{22}$ whereas the rims are $\mathrm{An}_{0}-\mathrm{An}_{8}$ and $A n_{10}-A n_{22}$. The TG suite shows overlap in plagioclase core and rim compositions whereas the GAG and GG suites show a more distinct compositional variation between core and rim as shown on the An-content versus frequency histogram (Figure 5a and b). Plagioclase rims in contact with $\mathrm{K}$-feldspar is dominantly lower in An compared to rims bordering quartz or other plagioclase. This variation is attributed to the existence of clear discontinuous rims on the 


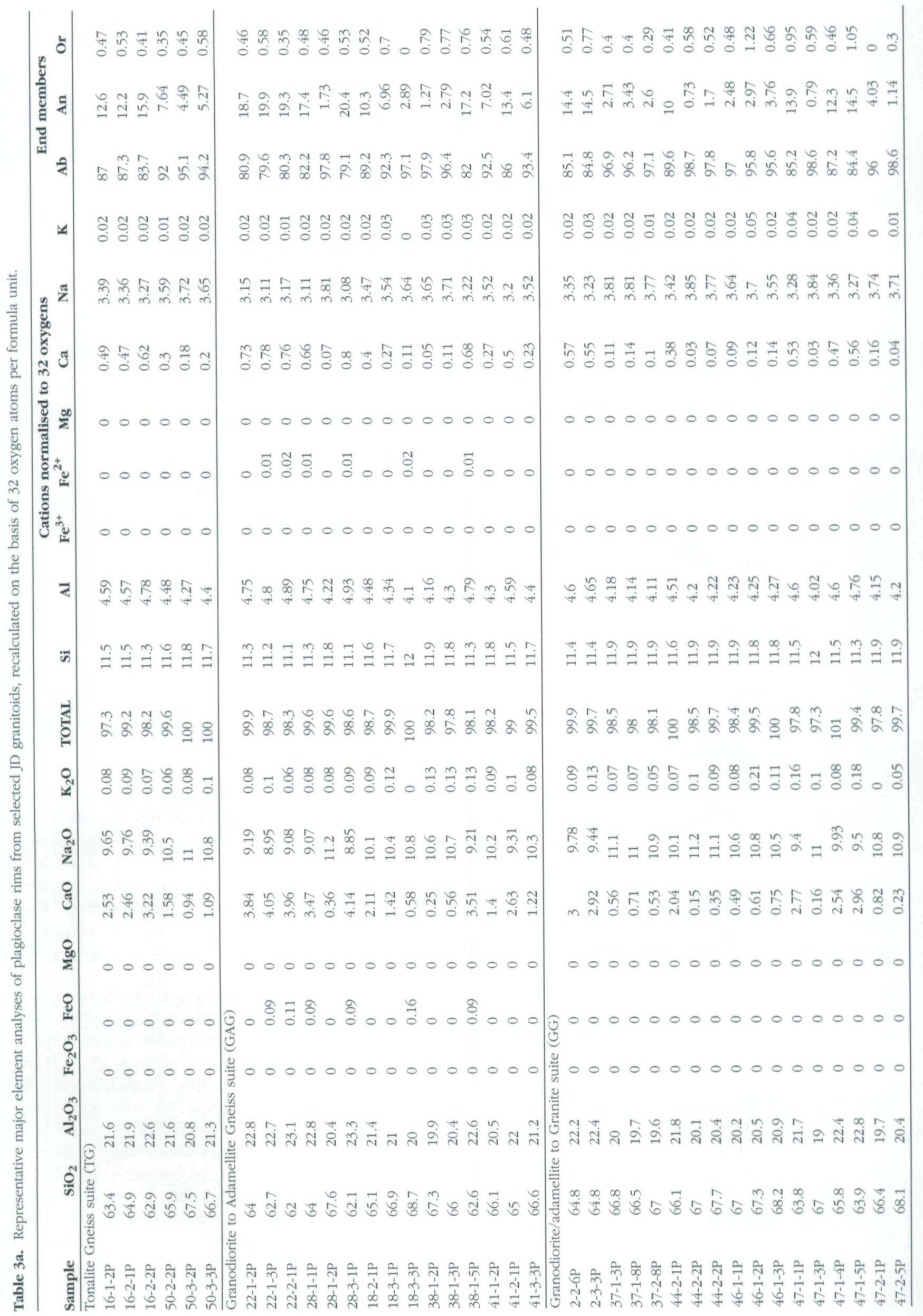




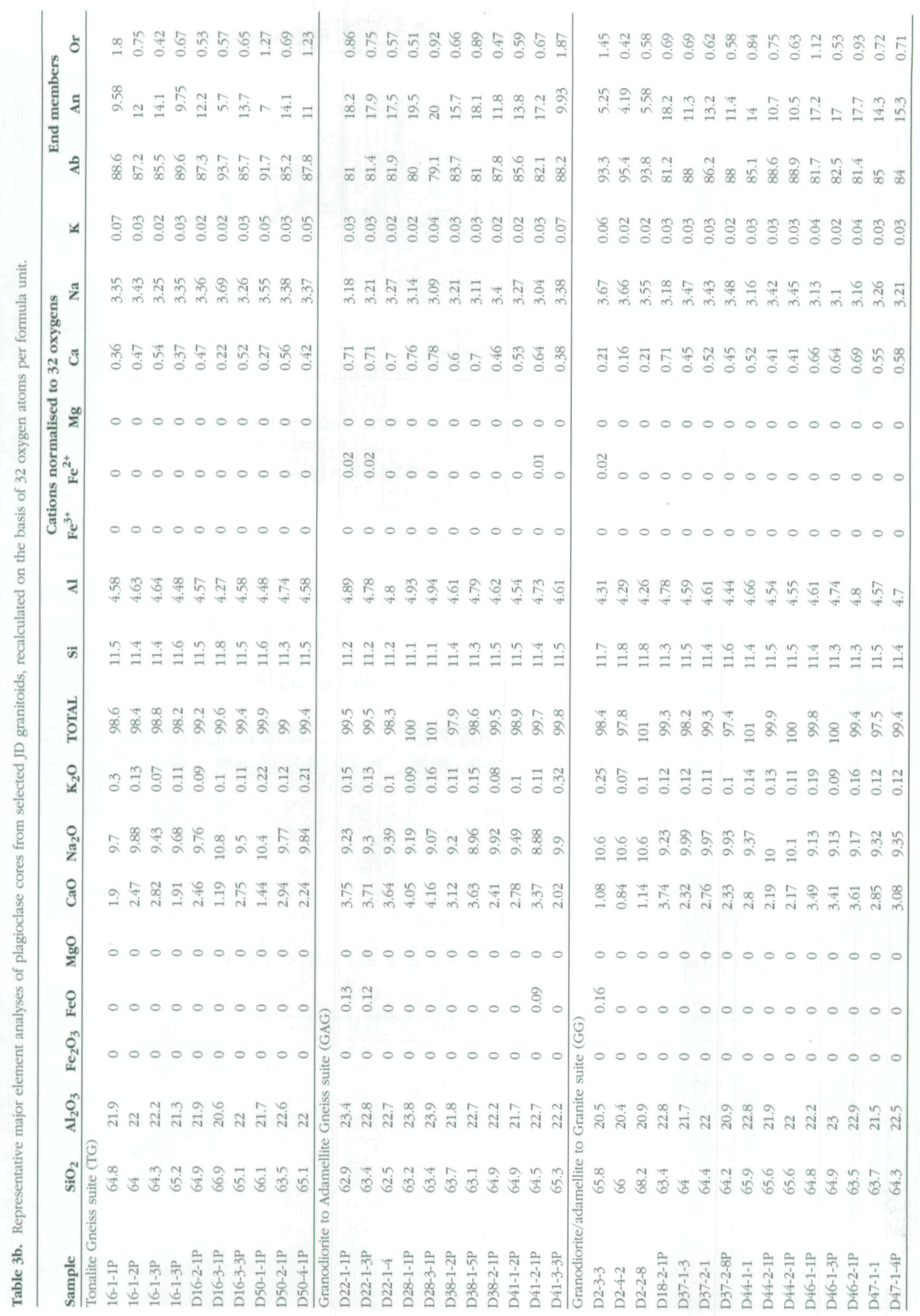



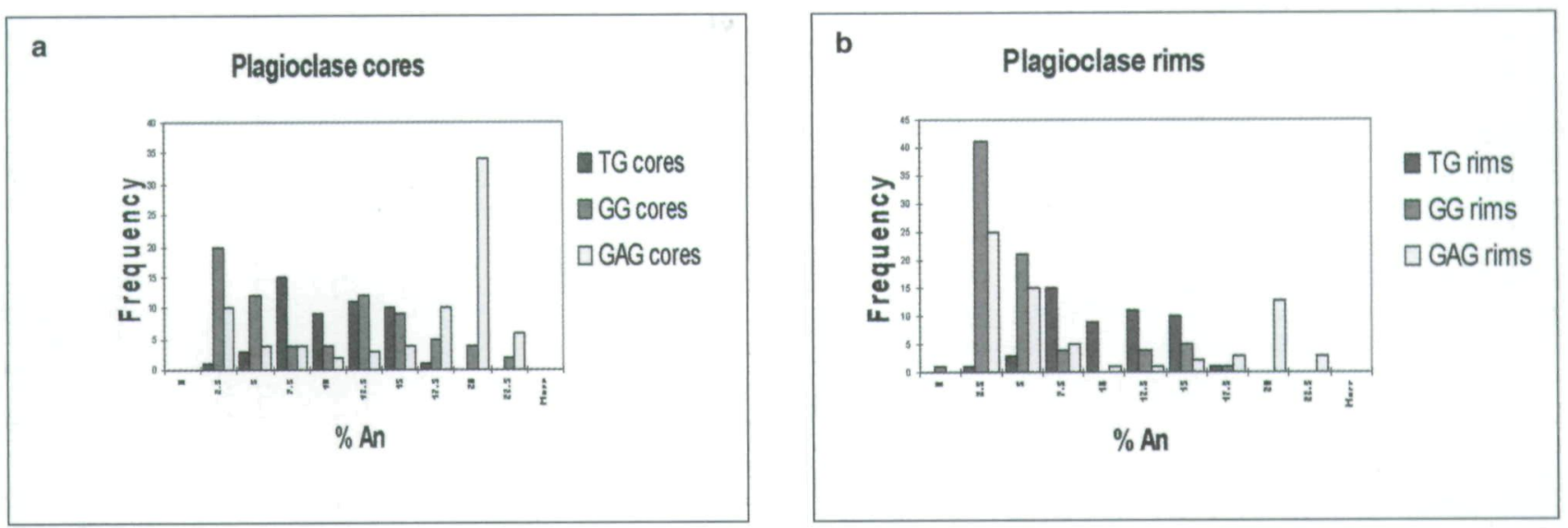

Figure 5. (a) Histograms of the An content vs frequency in plagioclase for cores in all three JD granitoid suites (b) Histograms of the An content vs frequency in plagioclase for rims in all three JD granitoid suites.

contacts between plagioclase and K-feldspar related to sub-solidus exsolution.

$\boldsymbol{K}$-feldspar occurs in all three suites but its proportions and morphology vary. K-feldspar is mainly microcline varying in size from fine to coarse-grained ( 0.5 to $4 \mathrm{~mm}$ ). It is present in small quantities in the TG suite whereas it is one of the main constituents of the GG and GAG suites. It is anhedral and interstitial to plagioclase tablets in the TG suite but granular, poikilitically enclosing smaller randomly orientated grains of quartz and euhedral plagioclase, in the GAG and GG suites.

Quartz occurs as fine to medium-grained $(0.32 \mathrm{~mm}$ to $5.8 \mathrm{~mm}$ in diameter) crystals and shows late magmatic to sub-solidus deformation (undulose extinction and sub-grain development along quartz-quartz grain boundaries). Three morphological varieties of quartz were identified in the JD granitoids, i.e. amoeboid,

Table 4. Representative major element analyses of amphibole from selected JD granitoids, recalculated on the basis of 24 oxygen atoms per formula unit

\begin{tabular}{|c|c|c|c|c|c|c|c|c|c|c|c|c|c|}
\hline \multirow[b]{2}{*}{ Sample } & \multirow[b]{2}{*}{ 16-2-1A } & \multirow[b]{2}{*}{ 16-2-1B } & \multicolumn{5}{|c|}{ Tonalite Gneiss Suite (TG) } & \multicolumn{6}{|c|}{ Granodiorite to Adamellite Gneiss suite (GAG) } \\
\hline & & & 16-2-1C & 16-2-1D & 50-1A & $50-1 B$ & $50-2 \mathrm{C}$ & 50-2D & 28-1A & 28-2B & 28-1C & $28-3 A$ & 28-3B \\
\hline$\overline{\mathrm{SiO}_{2}}$ & 50.6 & 45.6 & 48.8 & 45.1 & 48.8 & 45.3 & 44.7 & 45.5 & 47.5 & 48 & 47.5 & 47.6 & 50.9 \\
\hline $\mathrm{TiO}_{2}$ & 0.41 & 0.99 & 0.26 & 0.63 & 0.28 & 1.07 & 1.19 & 0.82 & 0.61 & 0.52 & 0.87 & 0.58 & 0.12 \\
\hline $\mathrm{Al}_{2} \mathrm{O}_{3}$ & 4.78 & 8.28 & 6.69 & 9.66 & 6.2 & 8.92 & 9.7 & 9.01 & 6.86 & 6.78 & 7.1 & 7.1 & 3.78 \\
\hline $\mathrm{Cr}_{2} \mathrm{O}_{3}$ & 0 & 0 & 0 & 0.06 & 0.07 & 0.05 & 0 & 0 & 0.08 & 0.06 & 0.15 & 0.07 & 0.08 \\
\hline $\mathrm{Fe}_{2} \mathrm{O}_{3}$ & 0 & 0 & 0 & 0 & 0 & 0 & 0 & 0 & 0 & 0 & 0 & 0 & 0 \\
\hline $\mathrm{FeO}$ & 13 & 16.7 & 15.3 & 18 & 15.2 & 17.2 & 17.4 & 18 & 14.8 & 15.2 & 15.1 & 14.9 & 11.9 \\
\hline $\mathrm{MnO}$ & 0.22 & 0.29 & 0.36 & 0.32 & 0.32 & 0.34 & 0.31 & 0.39 & 0.4 & 0.46 & 0.41 & 0.44 & 0.38 \\
\hline $\mathrm{MgO}$ & 14.5 & 11.7 & 13.3 & 11.1 & 13.6 & 11.4 & 11 & 11 & 13.6 & 13.8 & 13.3 & 13.6 & 14.9 \\
\hline $\mathrm{CaO}$ & 12.1 & 11.8 & 12.3 & 12.3 & 12.6 & 11.9 & 12.3 & 12.4 & 12.3 & 11.8 & 11.7 & 12.3 & 12.6 \\
\hline $\mathrm{Na}_{2} \mathrm{O}$ & 0.53 & 0.92 & 0.92 & 1.14 & 0.92 & 1.25 & 1.29 & 1.32 & 1.36 & 1.19 & 1.3 & 1.28 & 0.63 \\
\hline $\mathrm{K}_{2} \mathrm{O}$ & 0.39 & 0.83 & 0.44 & 0.89 & 0.4 & 0.92 & 1.12 & 1 & 0.74 & 0.77 & 0.76 & 0.79 & 0.32 \\
\hline TOTAL & 96.5 & 97.1 & 98.4 & 99.2 & 98.3 & 98.4 & 99 & 99.5 & 98.3 & 98.6 & 98.2 & 98.7 & 95.6 \\
\hline SI & 7.75 & 7.15 & 7.45 & 6.98 & 7.46 & 7.05 & 6.93 & 7.04 & 7.3 & 7.35 & 7.3 & 7.29 & 7.85 \\
\hline TI & 0.05 & 0.12 & 0.03 & 0.07 & 0.03 & 0.13 & 0.14 & 0.1 & 0.07 & 0.06 & 0.1 & 0.07 & 0.01 \\
\hline AL & 0.86 & 1.53 & 1.21 & 1.76 & 1.12 & 1.64 & 1.78 & 1.64 & 1.24 & 1.22 & 1.29 & 1.28 & 0.69 \\
\hline CR & 0 & 0 & 0 & 0.01 & 0.01 & 0.01 & 0 & 0 & 0.01 & 0.01 & 0.02 & 0.01 & 0.01 \\
\hline FE3 & 0 & 0 & 0 & 0 & 0 & 0 & 0 & 0 & 0 & 0 & 0 & 0 & 0 \\
\hline FE2 & 1.67 & 2.2 & 1.96 & 2.34 & 1.95 & 2.24 & 2.26 & 2.33 & 1.91 & 1.95 & 1.94 & 1.91 & 1.54 \\
\hline $\mathrm{MN}$ & 0.03 & 0.04 & 0.05 & 0.04 & 0.04 & 0.05 & 0.04 & 0.05 & 0.05 & 0.06 & 0.05 & 0.06 & 0.05 \\
\hline MG & 3.3 & 2.74 & 3.03 & 2.55 & 3.09 & 2.64 & 2.54 & 2.54 & 3.12 & 3.14 & 3.05 & 3.09 & 3.43 \\
\hline $\mathrm{CA}$ & 1.99 & 1.98 & 2.01 & 2.05 & 2.07 & 1.98 & 2.05 & 2.06 & 2.02 & 1.94 & 1.93 & 2.02 & 2.08 \\
\hline NA & 0.16 & 0.28 & 0.27 & 0.34 & 0.27 & 0.38 & 0.39 & 0.4 & 0.41 & 0.35 & 0.39 & 0.38 & 0.19 \\
\hline $\mathrm{K}$ & 0.08 & 0.17 & 0.09 & 0.18 & 0.08 & 0.18 & 0.22 & 0.2 & 0.15 & 0.15 & 0.15 & 0.15 & 0.06 \\
\hline SUM & 15.9 & 16.2 & 16.1 & 16.3 & 16.1 & 16.3 & 16.3 & 16.3 & 16.3 & 16.2 & 16.2 & 16.3 & 15.9 \\
\hline
\end{tabular}




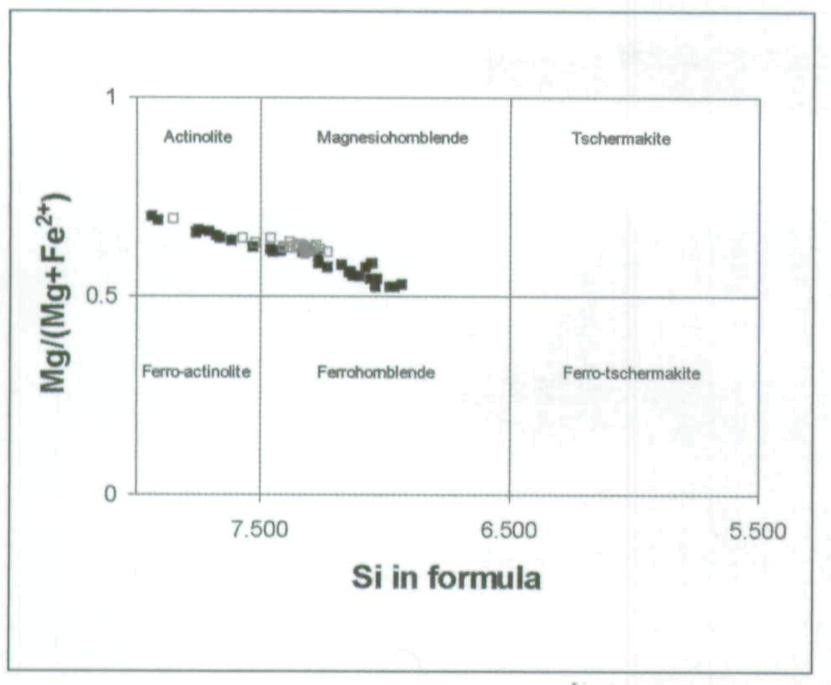

Figure 6. Classification diagram for amphiboles from the TG (solid black symbol) and GAG suite tonalite trondhjemite gneiss (open red symbol) of the JD.

interstitial, and rounded to vermicular. Myrmekitic intergrowths of plagioclase and quartz are developed along plagioclase grain boundaries.

Biotite is fine-grained brown-green $(0.1$ to $0.2 \mathrm{~mm}$ in size) and occurs as individual crystals or aggregates associated with hornblende, sphene, apatite, chlorite, epidote and zircon. These aggregates have a preferred orientation contributing to the gneissic foliation observed in the TG and GAG suites. Biotite is slightly altered to chlorite, muscovite and titanite.

Amphibole is the dominant ferromagnesian mineral in the TG suite and locally developed in the tonalitic to trondhjemitic gneiss of the GAG suite. It forms palegreen to dark yellow-green anhedral crystal aggregates and isolated subhedral crystals. Amphibole grains are either uniformly scattered throughout the rock or cluster together with biotite, sphene, apatite, chlorite, epidote and zircon defining the gneissic foliation. Amphibole crystals commonly enclose mainly quartz in a poikilitic fashion. Minor chloritization of hornblende and biotite is not uncommon but chlorite generally makes up $<1$ volume \%. Microprobe analyses of the TG and GAG suites showed amphiboles are calcic (Table 4). Compositions in the TG suite range from actinolite to magnesiohornblende, whereas in the GAG suite it is mostly magnesiohornblende (Figure 6). The $\mathrm{Mg} /(\mathrm{Mg}+$ $\mathrm{Fe}^{2+}$ ) ratios of amphibole for both the TG and GAG suites range from 0.52 to 0.70 .

Epidote is a prominent accessory mineral and occurs as faintly to conspicuously pleochroic crystals in all JD granitoids, but more prominently in the TG suite. This mineral not only forms the sub-solidus alteration of plagioclase, but also as individual crystals in mafic mineral clots or as rims on some allanites.

\section{Whole rock geochemistry}

Full major and trace element compositions are given in Table 5 .

\section{Major element composition}

The alumina saturation of the JD rocks is shown in Figure 7, a plot of molar $\mathrm{A} / \mathrm{CNK}$ vs $\quad \mathrm{wt} \% \quad \mathrm{SiO}_{2}$ (Chapell and White, 1974). The JD is dominantly I-type (>1.1 A/CNK), peraluminous rocks but the older tonalites (TG and GAG suites) fall in the metaluminous field. Also shown on the diagram is published data from across the JD (Anhaeusser, 1973) as well as the isolated Nooitgedacht outcrop Anhaeusser, 1999). On the Q-P $(\mathrm{Q}=\mathrm{Si} / 3-(\mathrm{K}+\mathrm{Na}+2 \mathrm{Ca} / 3)$ and $\mathrm{P}=\mathrm{K}-(\mathrm{Na}+\mathrm{Ca}))$ major element-based lithological classification diagram of Debon and Le Fort (1982) (Figure 8) the TG suite tonalite gneiss straddles the tonalite and granodiorite fields. The GAG suite plots almost exclusively in the adamellite and granodiorite field, whereas the locally

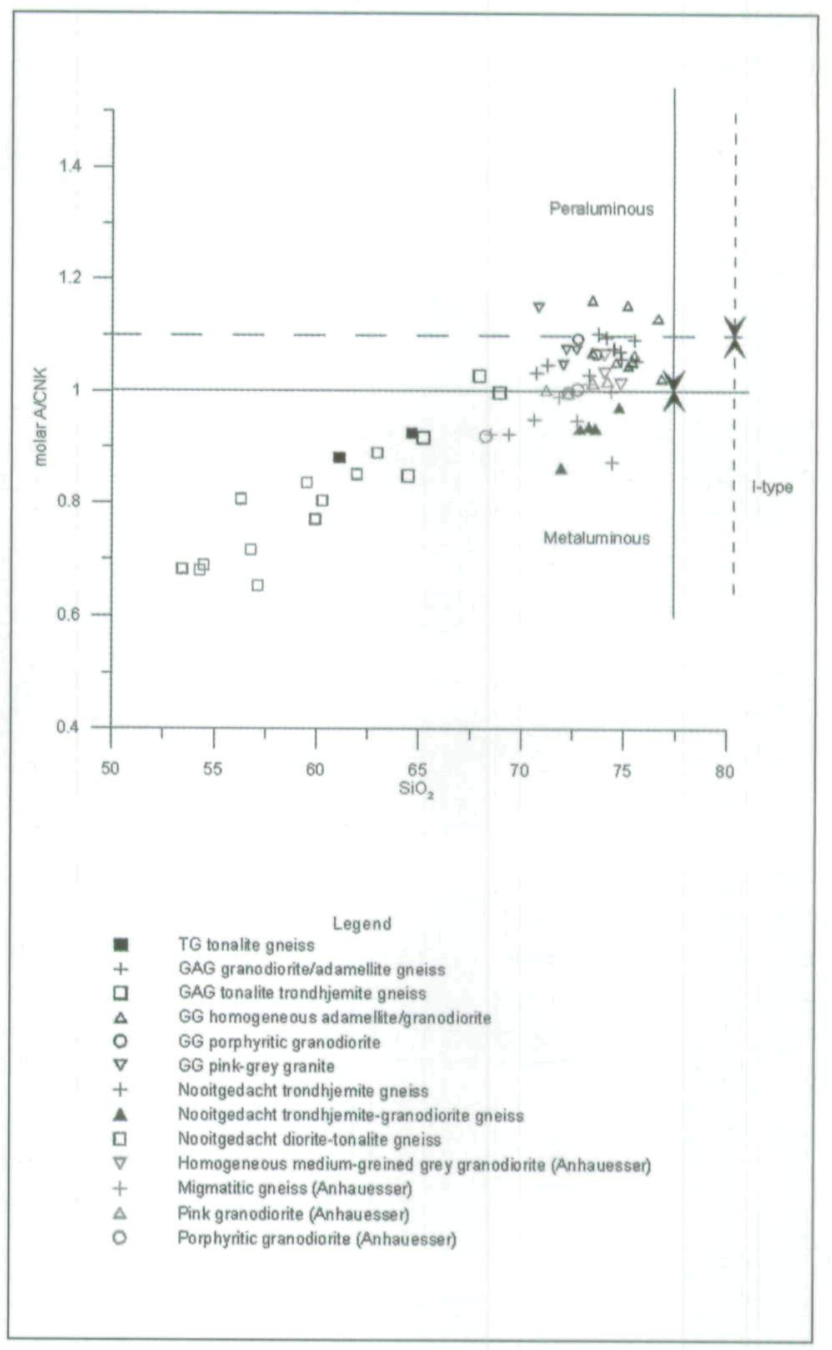

Figure 7. Alumina-saturation diagram ( $\mathrm{A} / \mathrm{CNK}$ vs $\mathrm{SiO}_{2}$ ) (Chappel and White, 1992) showing JD granitoids (excluding Nooitgedacht rocks (blue symbols) fall dominantly in the I-type $(<1.1 \mathrm{~A} / C N K)$ but peraluminous granite $(A / C N K>1)$ field with mainly tonalites (TG and GAG suites) falling in the metaluminous $(A / C N K<1)$ field. 


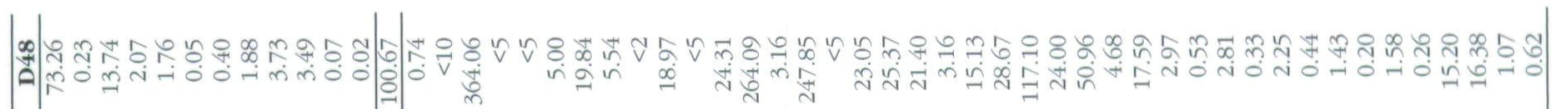

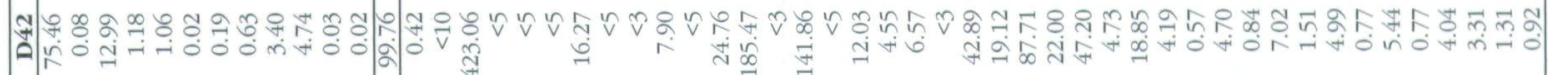

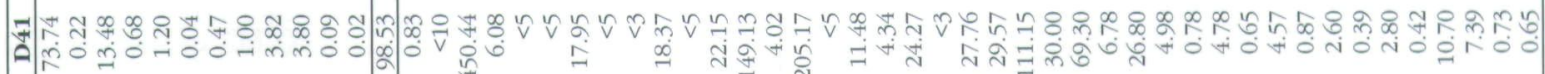

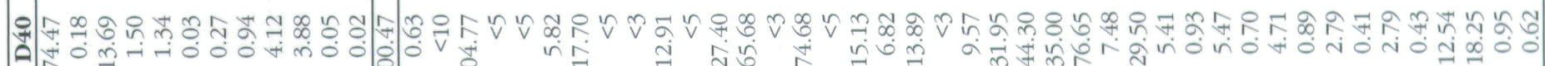

m.

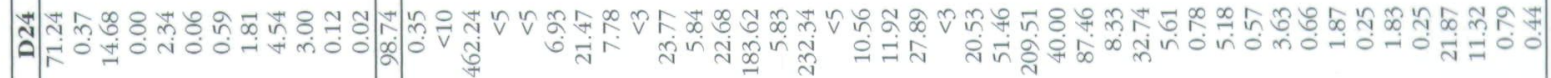

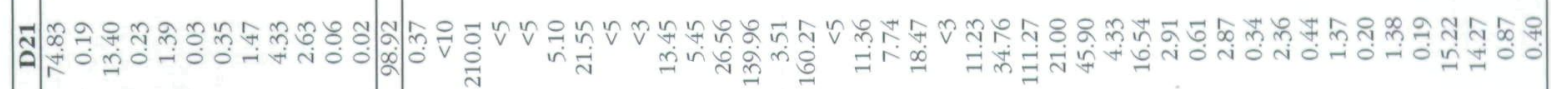

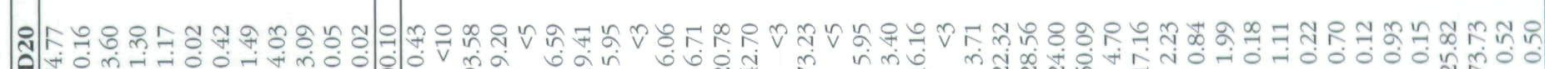

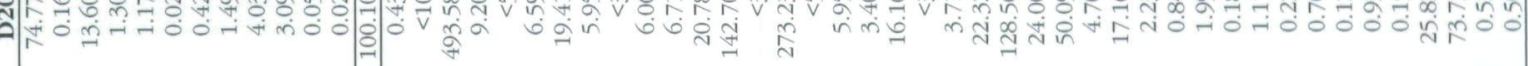

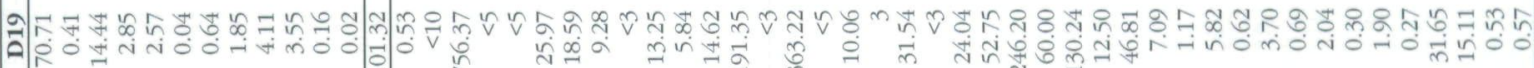

a g o

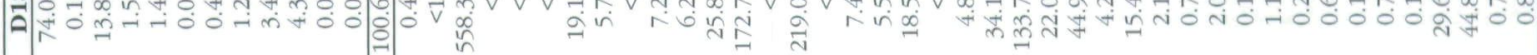
की

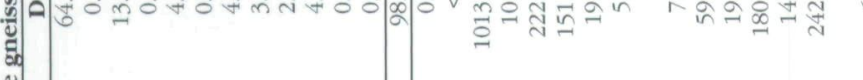

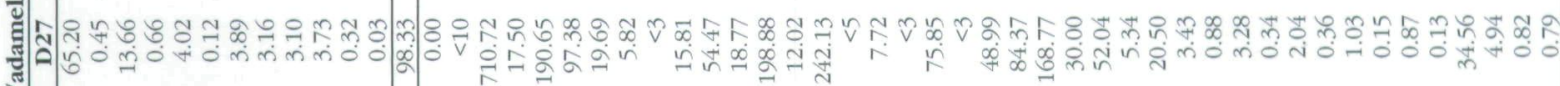

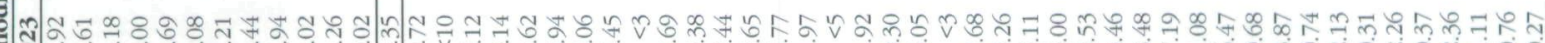
वी.

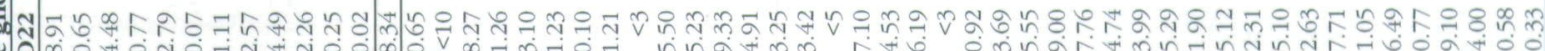

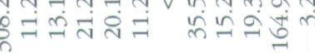

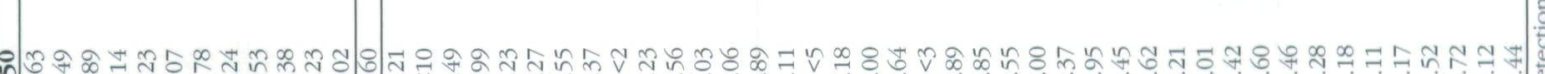

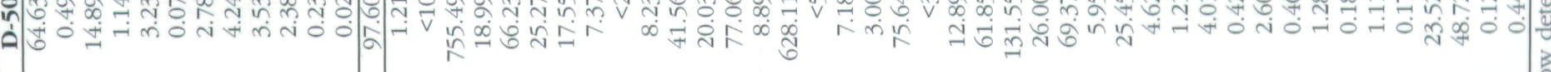

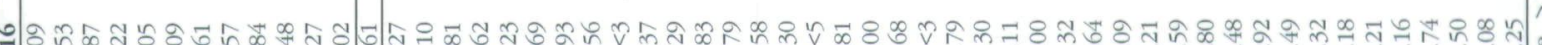

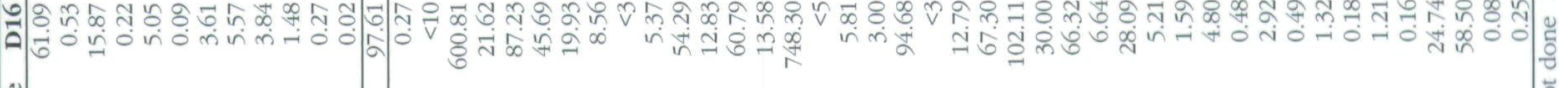

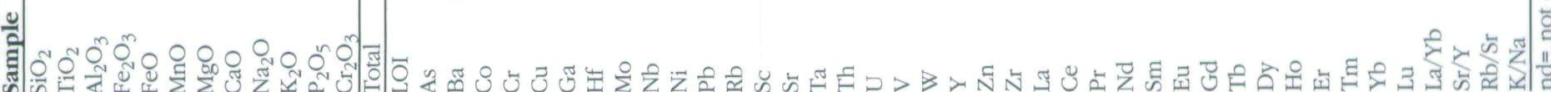


|⿹丁口

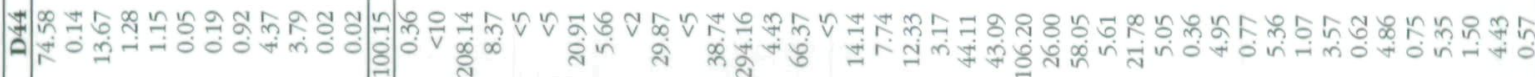

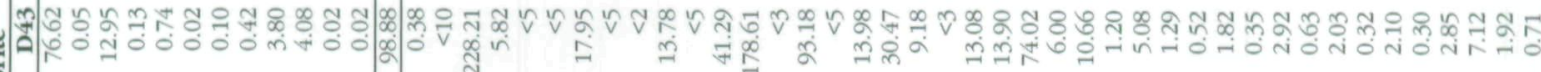

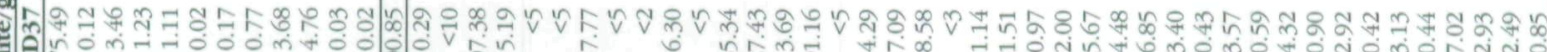

月ी 要

m. 氖

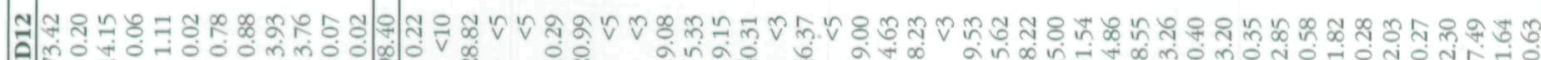

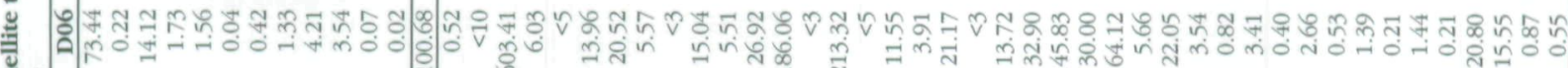

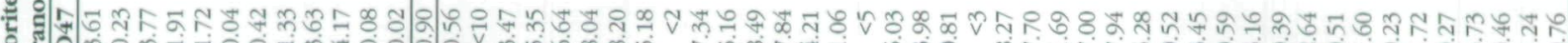
造

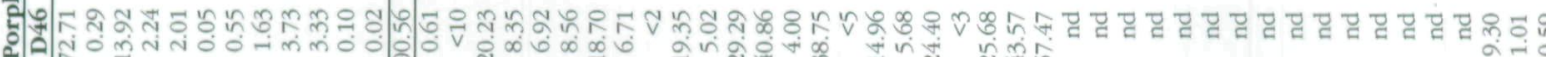

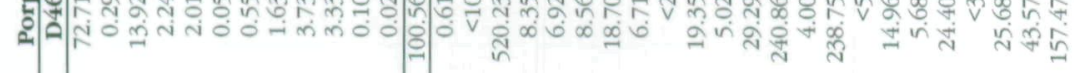

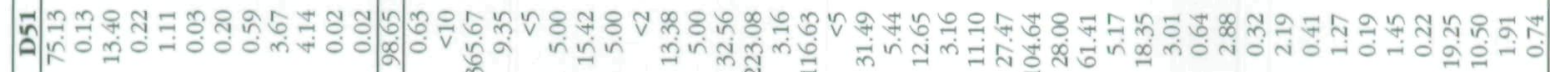

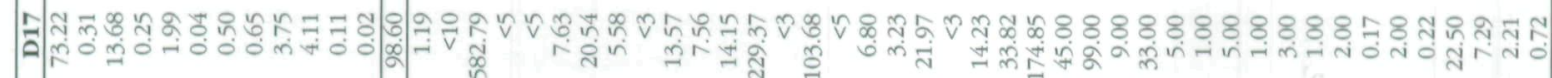
$\because$

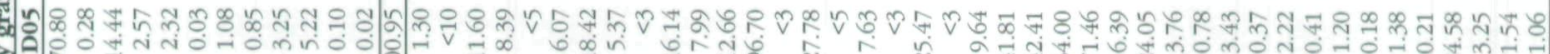

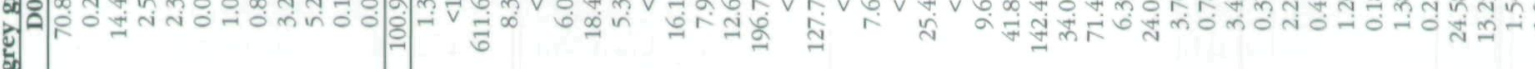

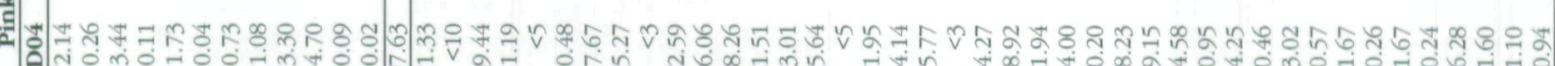

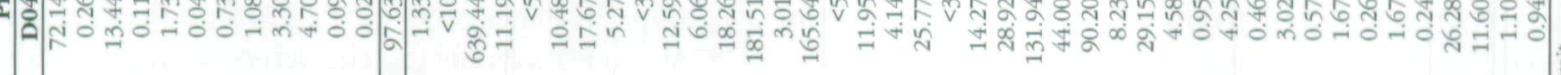
送

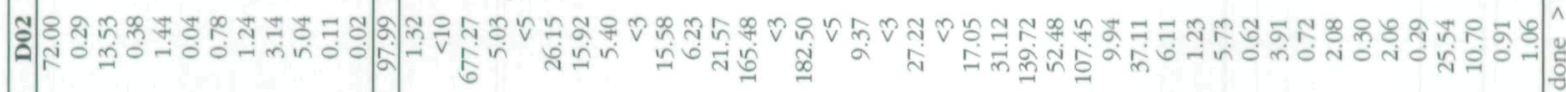

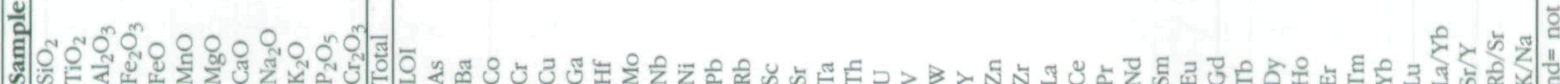




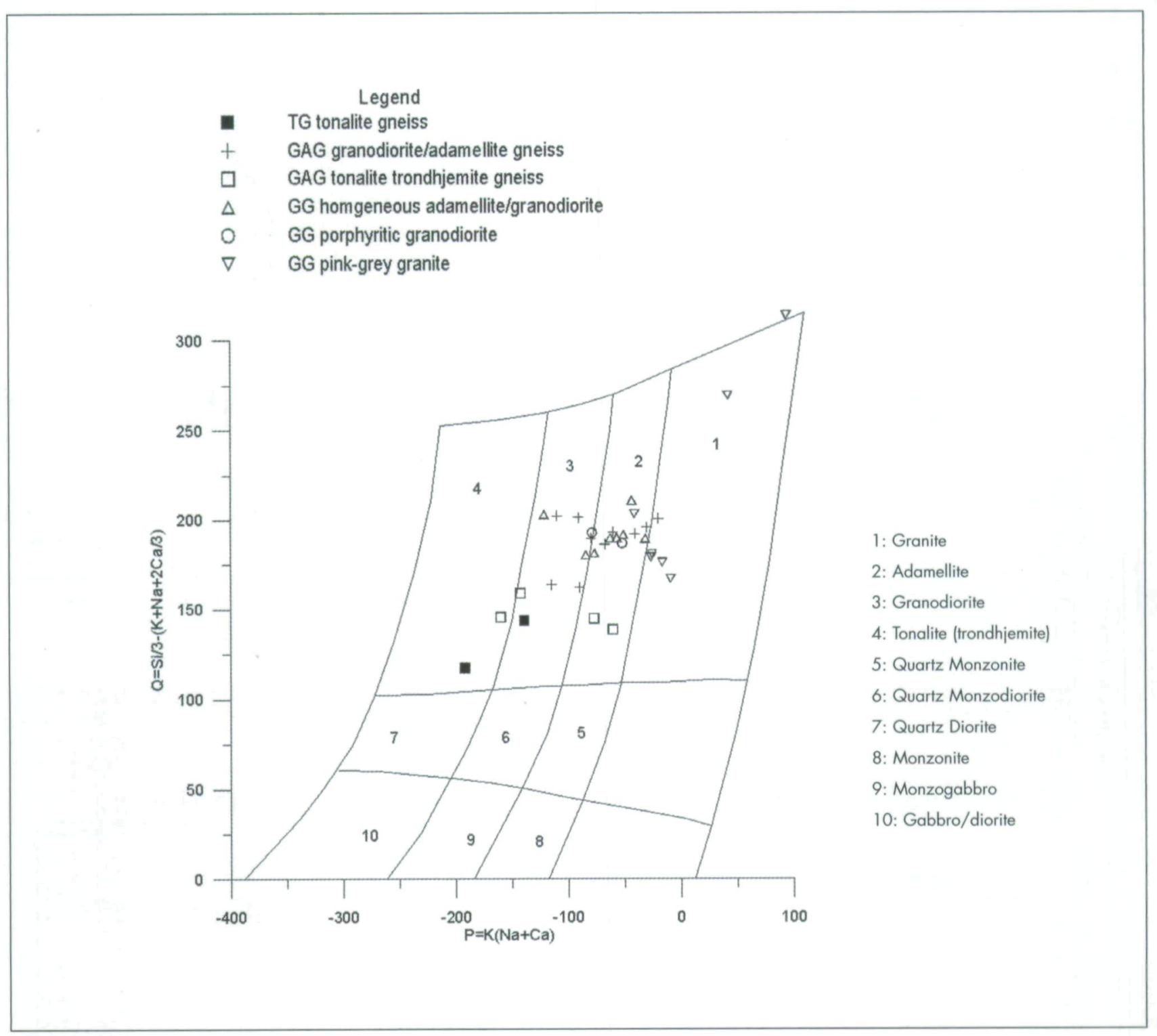

Figure 8. The various plutonic units of the JD plotted on the Q-P major-element-based granitoid classification diagram of Debon and Le Fort (1982) $((Q=S i / 3-(K+N a+2 C a / 3)$ and $P=K-(N a+C a))$.

developed tonalite to trondhjemite gneiss falls within the granodiorite and tonalite fields. The GG suite plots as granite, adamellite and granodiorite.

The JD rocks are dominantly high silica ( 70 weight $\%$ ), aluminous $\left(\mathrm{A}_{2} \mathrm{O}_{3}>15 \mathrm{wt} \%\right)$, high $\mathrm{Na}_{2} \mathrm{O} / \mathrm{K}_{3} \mathrm{O}(>1)$ rocks with $\mathrm{Na}_{2} \mathrm{O}$ contents ( 3 weight $\%$ and 5 weight $\%$ ), which compare with the average TTG compositions (Table 5). The geochemical compositions of the JD granitoids define two broad groupings (with a minor overlap):

i. the first group is characterised by relatively high content of $\mathrm{MgO}\left(>1\right.$ weight \%) and $\mathrm{SiO}_{2}$ ranging between 60 and 70 weight \% (mainly the older TG suite and some GAG suite tonalite-trondhjemite gneiss); and

ii. a second group characterised by much higher content of $\mathrm{SiO}_{2}(>70$ weight \%) but lower content of $\mathrm{MgO}$ ( $<1$ weight \%) represented by the younger rocks (GAG and GG suites).
Except for the relatively high $\mathrm{MgO}$ content (up to $>9$ weight $\%$ in the TG suite and the GAG suite tonalitetrondhjemite gneiss) the JD granitoids are generally charcaterised by low contents $(<5$ weight \%) of $\mathrm{Fe}_{2} \mathrm{O}_{3}+\mathrm{MgO}+\mathrm{MnO}+\mathrm{TiO}_{2}$ (Table 4). The majority of the JD granitoids have $\mathrm{FeO}$ contents below that of the average TTG suite $(\sim 3$ weight \%). The high-MgO group (TG suite and tonalite-to-trondhjemite gneiss of GAG suite) exhibits the characteristic $\mathrm{Na}_{2} \mathrm{O} / \mathrm{K}_{2} \mathrm{O}>1$ seen in TTG suites.

A range of major element Harker variation diagrams is used for characterization of JD rocks including data from previous studies (Anhaeusser, 1973; 1999) and shown in Figure 9. Most oxides in the JD suites are negatively correlated with $\mathrm{SiO}_{2}$ as shown in the Harker diagrams for $\mathrm{Al}_{2} \mathrm{O}_{3}, \mathrm{MgO}, \mathrm{TiO}_{2}, \mathrm{FeO}, \mathrm{MnO}$ and $\mathrm{CaO}$ vs wt $\% \mathrm{SiO}_{2}$. However, exceptions are observed concerning the alkalis $\left(\mathrm{Na}_{2} \mathrm{O}\right.$ and $\left.\mathrm{K}_{2} \mathrm{O}\right)$, which show 
Table 6. Major, trace and RE element variations in average TTG and other relevant rock types

\begin{tabular}{|c|c|c|c|c|c|c|c|c|c|c|c|c|c|}
\hline & $\begin{array}{c}\text { Avg } \\
\text { TTG } \\
>3.5 \mathrm{Ga}\end{array}$ & $\begin{array}{c}\text { Avg } \\
\text { TrG } \\
3-3.5 \mathrm{Ga}\end{array}$ & $\begin{array}{c}\text { Avg } \\
\text { TTG } \\
<3 \mathrm{Ga} \\
\end{array}$ & $\begin{array}{c}\text { Modern } \\
\text { Arc } \\
\text { Granitoid }\end{array}$ & Sanukitoid & $\begin{array}{c}\text { Closepet } \\
\text { type } \\
\text { granite }\end{array}$ & GGM & HSA & LSA & $\begin{array}{c}\text { Avg } \\
\text { upper } \\
\text { crust } \\
\end{array}$ & $\begin{array}{c}\text { Avg } \\
\text { lower } \\
\text { crust } \\
\end{array}$ & $\begin{array}{c}\text { Avg P } \\
\text { continental } \\
\text { crust } \\
\end{array}$ & $\begin{array}{l}\text { Primitive } \\
\text { Mantle }\end{array}$ \\
\hline & 1 & 2 & 3 & 4 & 5 & 6 & 7 & 8 & 9 & 10 & 11 & 12 & 13 \\
\hline $\mathrm{SiO}_{2}$ & 69.59 & 69.65 & 68.36 & 68.1 & 58.76 & 56.39 & 72.06 & 64.8 & 56.25 & 66 & 54.4 & 57.3 & \\
\hline $\mathrm{TiO}_{2}$ & 0.39 & 0.36 & 0.38 & & 0.74 & 1.2 & 0.34 & 0.56 & 1.49 & 0.5 & 1 & 0.9 & \\
\hline $\mathrm{Al}_{2} \mathrm{O}_{3}$ & 15.29 & 15.35 & 15.52 & 15.07 & 15.8 & 15.79 & 14.59 & 16.64 & 15.29 & 15.2 & 16.1 & 15.9 & \\
\hline $\mathrm{Fe}_{2} \mathrm{O}_{3}$ & 3.26 & 3.07 & 3.27 & 4.36 & 5.87 & 7.34 & . & 4.75 & 3.26 & & & & \\
\hline $\mathrm{FeO}$ & - & - & - & - & - & - & 1.75 & - & - & 4.5 & 10.6 & 9.1 & \\
\hline $\mathrm{MnO}$ & 0.04 & 0.06 & 0.05 & 0.09 & 0.09 & 0.13 & 0.02 & 0.08 & 0.09 & & & & \\
\hline $\mathrm{MgO}$ & 1 & 1.07 & 1.36 & 1.55 & 3.9 & 3.38 & 0.59 & 2.18 & 5.15 & 2.2 & 6.3 & 5.3 & \\
\hline $\mathrm{CaO}$ & 3.03 & 2.96 & 3.23 & 3.06 & 5.57 & 5.45 & 1.68 & 4.63 & 7.69 & 4.2 & 8.5 & 7.4 & \\
\hline $\mathrm{Na}_{2} \mathrm{O}$ & 4.6 & 4.64 & 4.7 & 3.68 & 4.42 & 3.94 & 4.87 & 4.19 & 4.11 & 3.9 & 2.8 & 3.1 & \\
\hline $\mathrm{K}_{2} \mathrm{O}$ & 2.04 & 1.74 & 2 & 3.4 & 2.78 & 3.17 & 4.18 & 1.97 & 2.37 & 3.4 & 0.3 & 1.1 & \\
\hline $\mathrm{P}_{2} \mathrm{O}_{5}$ & 0.13 & 0.14 & 0.15 & 0.15 & 0.39 & 0.72 & 0.1 & 0.2 & 0.66 & 0.1 & 0.1 & 0.1 & \\
\hline $\mathrm{Mg} \#$ & 0.38 & 0.41 & 0.45 & 0.41 & 0.57 & 0.48 & & 0.48 & 0.61 & & & & \\
\hline $\mathrm{Na}_{2} \mathrm{O} / \mathrm{K}_{2} \mathrm{O}$ & 0.44 & 0.38 & 0.43 & 0.92 & 0.63 & 0.8 & & 0.47 & 0.58 & & & & \\
\hline $\mathrm{Rb}$ & 79 & 59 & 67 & 110 & 65 & 93 & 139 & 19 & 52 & 110 & 11 & 61 & 0.635 \\
\hline $\mathrm{Ba}$ & 449 & 523 & 847 & 715 & 1543 & 1441 & 796 & 1087 & 721 & 700 & 757 & 707 & 6.989 \\
\hline $\mathrm{Nb}$ & 8 & 6 & 7 & 12.1 & 10 & 18 & 10.1 & 11 & 6 & 25 & 5 & 13 & 0.713 \\
\hline $\mathrm{Sr}$ & 360 & 429 & 541 & 316 & 1170 & 978 & 291 & 2051 & 565 & 350 & 569 & 503 & 21.1 \\
\hline $\mathrm{Zr}$ & 166 & 155 & 154 & 171 & 184 & 323 & 282 & 188 & 108 & 240 & 202 & 210 & 11.2 \\
\hline $\mathrm{Y}$ & 12 & 14 & 11 & 26 & 18 & 37 & 18.9 & 13 & 10 & 22 & 7 & 14 & 4.55 \\
\hline $\mathrm{Ni}$ & 12 & 15 & 21 & 10.5 & 72 & 38 & 7 & 103 & 20 & 20 & 135 & 105 & \\
\hline $\mathrm{Cr}$ & 34 & 21 & 50 & 23 & 128 & 50 & 10.4 & 157 & 41 & 35 & 235 & 185 & \\
\hline V & 39 & 43 & 52 & 76 & 95 & 129 & 19.4 & 184 & 95 & 60 & & & \\
\hline $\mathrm{La}$ & 35.3 & 31.4 & 30.8 & 31 & 59.9 & 90.9 & 72.9 & 41.1 & 19 & 30 & 22 & 28 & 0.687 \\
\hline $\mathrm{Ce}$ & 61.7 & 55.1 & 58.5 & 67 & 126 & 188 & 144 & 89.8 & 37.7 & 64 & 44 & 57 & 1.775 \\
\hline $\mathrm{Nd}$ & 25.8 & 19.6 & 23.2 & 27 & 54.8 & 84.9 & 49.3 & 47.1 & 18.2 & 26 & 18.5 & 23 & 1.354 \\
\hline $\mathrm{Sm}$ & 4.2 & 3.3 & 3.5 & 5.3 & 9.8 & 14.5 & 7.64 & 7.8 & 3.4 & 4.5 & 3.3 & 4.1 & 0.444 \\
\hline $\mathrm{Eu}$ & 1 & 0.8 & 0.9 & 1 & 2.3 & 3.2 & 1.23 & 2 & 0.9 & 0.88 & 1.17 & 1.1 & 0.168 \\
\hline Gd & 3.2 & 2.4 & 2.3 & 5.5 & 6 & 9.2 & 5.41 & 4.8 & 2.8 & 3.8 & 3.13 & 3.3 & 0.596 \\
\hline Dy & 1.8 & 1.9 & 1.6 & 5.2 & 3.2 & 5.6 & 3.65 & 2.8 & 1.9 & 3.5 & 3.6 & 3.7 & 0.737 \\
\hline Er & 0.77 & 0.77 & 0.75 & 3 & 1.41 & 2.68 & 1.97 & 1.21 & 0.96 & 2.3 & 2.2 & 2.2 & 0.48 \\
\hline $\mathrm{Yb}$ & 0.78 & 0.63 & 0.63 & 3.2 & 1.32 & 2.05 & 1.9 & 0.93 & 0.88 & 2.2 & 1.2 & 1.53 & 0.493 \\
\hline $\mathrm{Lu}$ & 0.2 & 0.13 & 0.12 & 0.5 & 0.26 & 0.34 & 0.29 & 0.08 & 0.17 & 0.32 & 0.29 & 0.3 & 0.074 \\
\hline $\mathrm{Sr} / \mathrm{Y}$ & 30.45 & 31.44 & 51.1 & & 63.89 & 26.58 & & 162.21 & 55.65 & & & & \\
\hline$(\mathrm{La} / \mathrm{Yb}) \mathrm{N}$ & 29.85 & 32.86 & 32.52 & & 29.92 & 29.32 & & 29.32 & 14.44 & & & & \\
\hline
\end{tabular}

\footnotetext{
1. Average of 108 TTGs (Martin et al., 2005)

2. Average of 320 TTGs (Martin et al., 2005)

3. Average of 666 TTGs (Martin et al., 2005)

4. Average of 250 arc granitoids (Martin, 1994)

5. Average of 31 sanukitoids (Martin et al., 2005)

6. Average of 31 Closepet-type granites $\left(<62 \% \mathrm{SiO}_{2}\right.$ ) (Martin et al., 2005)

7. Nelspruit pluton (Kleinhans et al., 2003)

8. Average of 267 High Silica Adakites (Martin et al., 2005)

9. Average of 77 Low Silica Adakites (Martin et al., 2005)

10. Taylor and McLennan (1981)

11. Weaver and Tarney (1984)

12. Weaver and Tarney (1984)

13. Sun and McDonough (1989)
}

scattered trends. In the case of $\mathrm{K}_{2} \mathrm{O}$ vs $\mathrm{SiO}_{2}$, however, there is a slight correlation for the major part of the data. A strong inverse correlation trend exists between $\mathrm{K}_{2} \mathrm{O}$ and $\mathrm{Na}_{2} \mathrm{O}$. The older (TG and GAG tonalite trondhjemite gneiss) rocks are enriched in most elements accept $\mathrm{K}_{2} \mathrm{O}$ and $\mathrm{Na}_{2} \mathrm{O}$ relative to the of the younger (GAG granodiorite/adamellite gneiss and GG) suites. The plots of $\mathrm{wt} \% \mathrm{FeO}$ and $\mathrm{MgO}$ vs wt $\% \mathrm{SiO}_{2}$ broadly show decreasing $\mathrm{FeO}$ and $\mathrm{MgO}$ with increasing $\mathrm{SiO}_{2}$. The $\mathrm{Mg} \#$ for the JD rocks ranges between 0.1 and 0.5 with the 
274

PETROLOGY AND GEOCHEMISTRY OF THE GRANITOID ROCKS OF THE JOHANNESBURG DOME
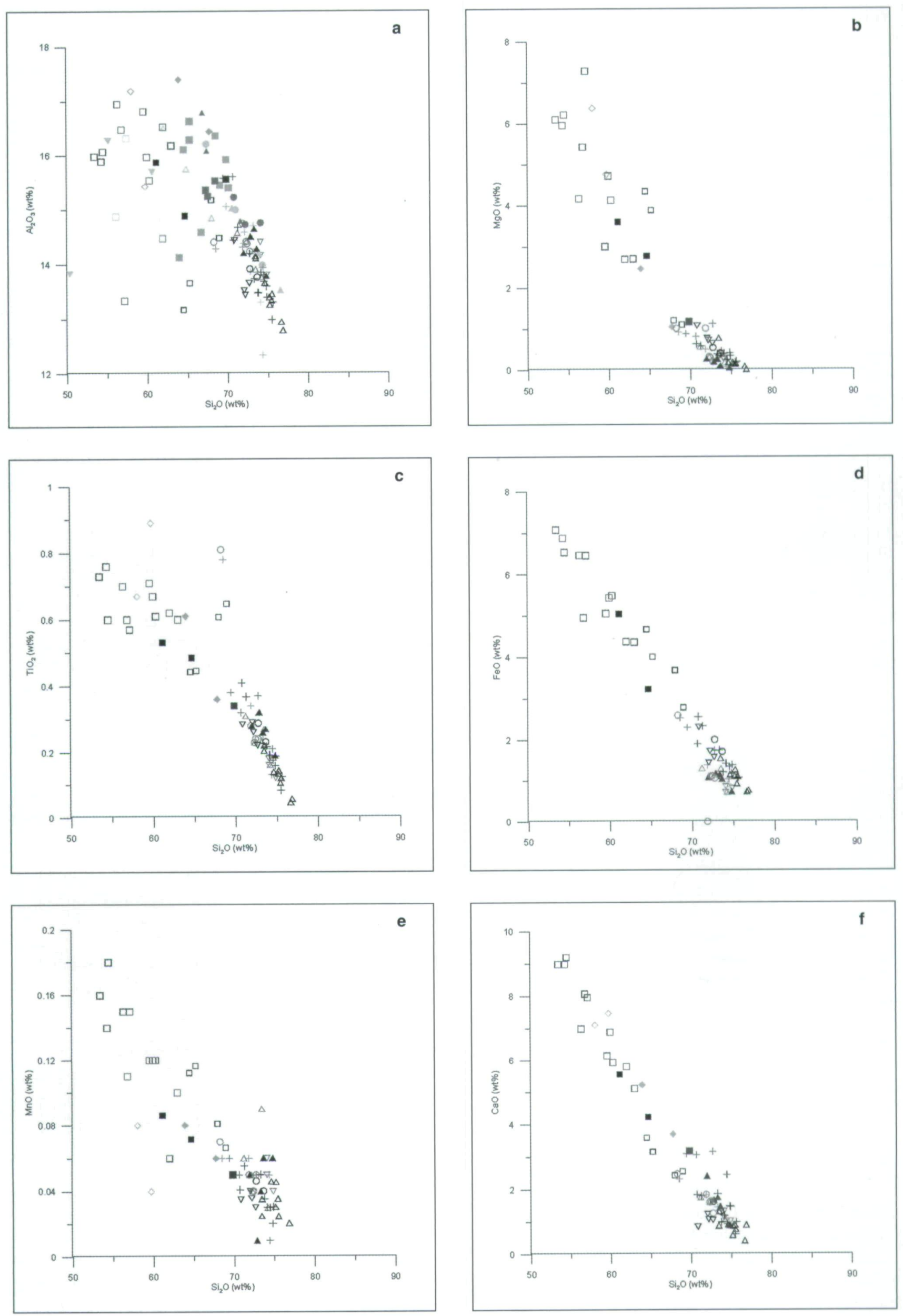

SOUTH AFRICAN JOURNAL OF GEOLOGY 

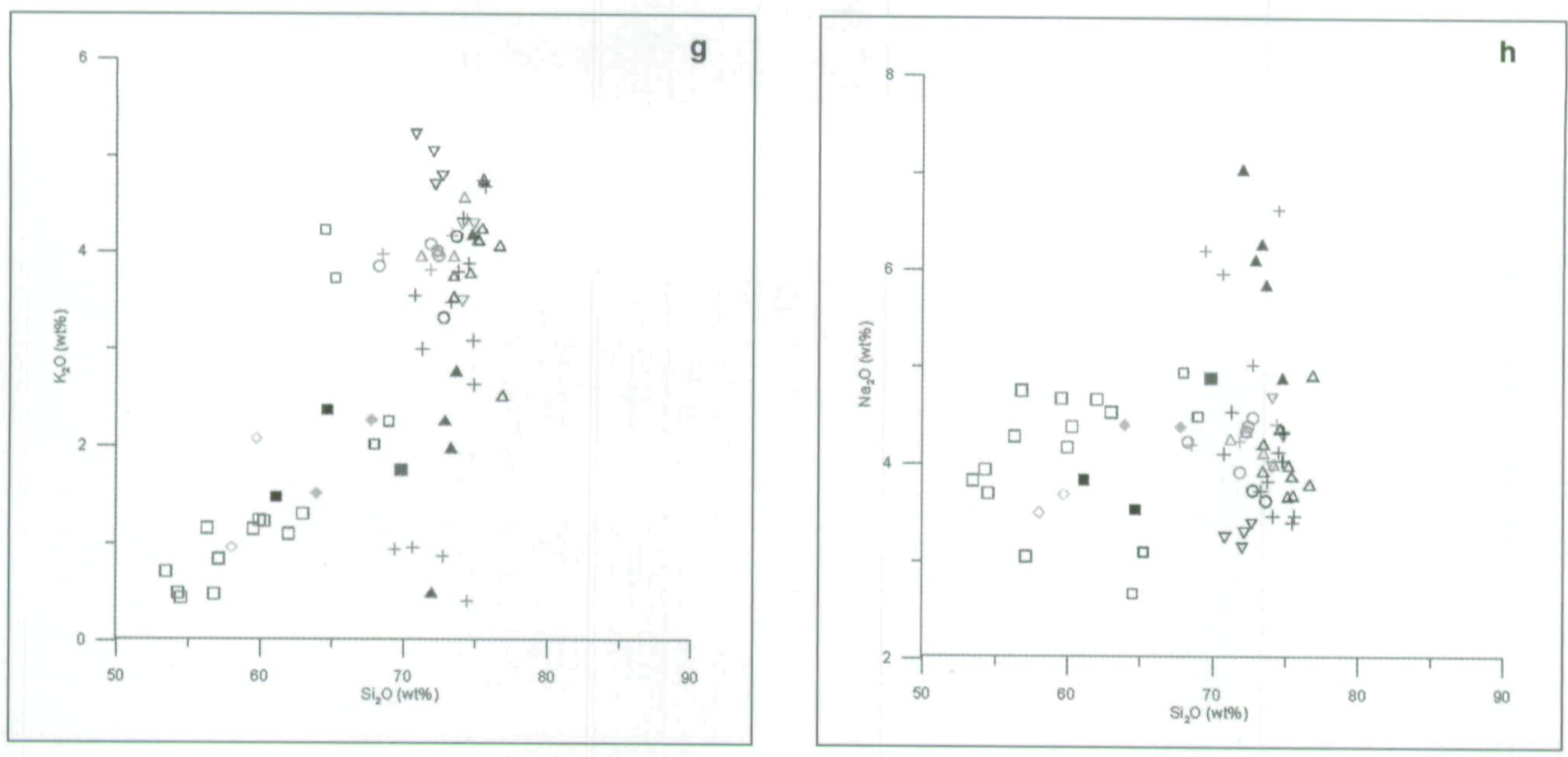

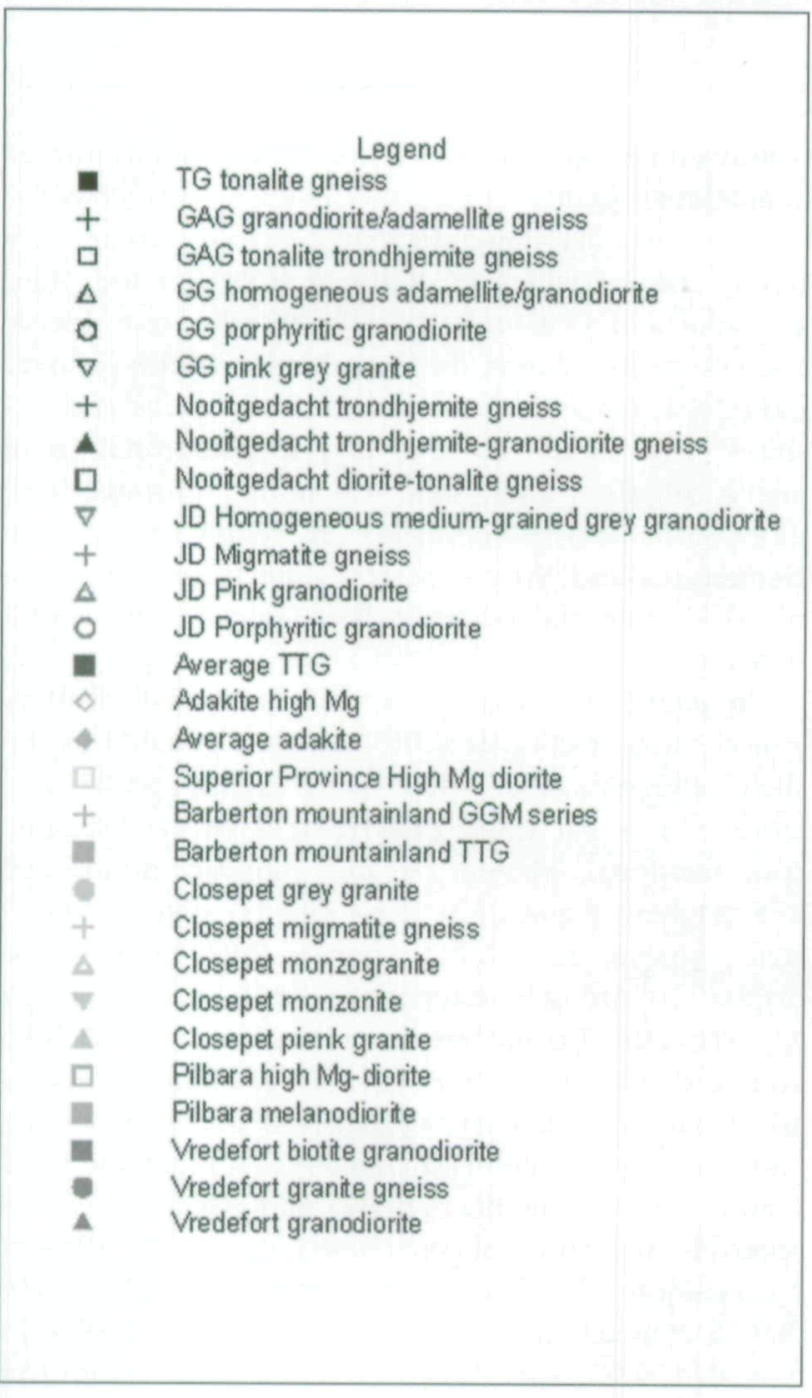

Figure 9. Major element Harker variation diagrams for the JD granitoids. Also included are data from previous studies (including average TTG, average adakite and average bigh $\mathrm{Mg}$ adakite).

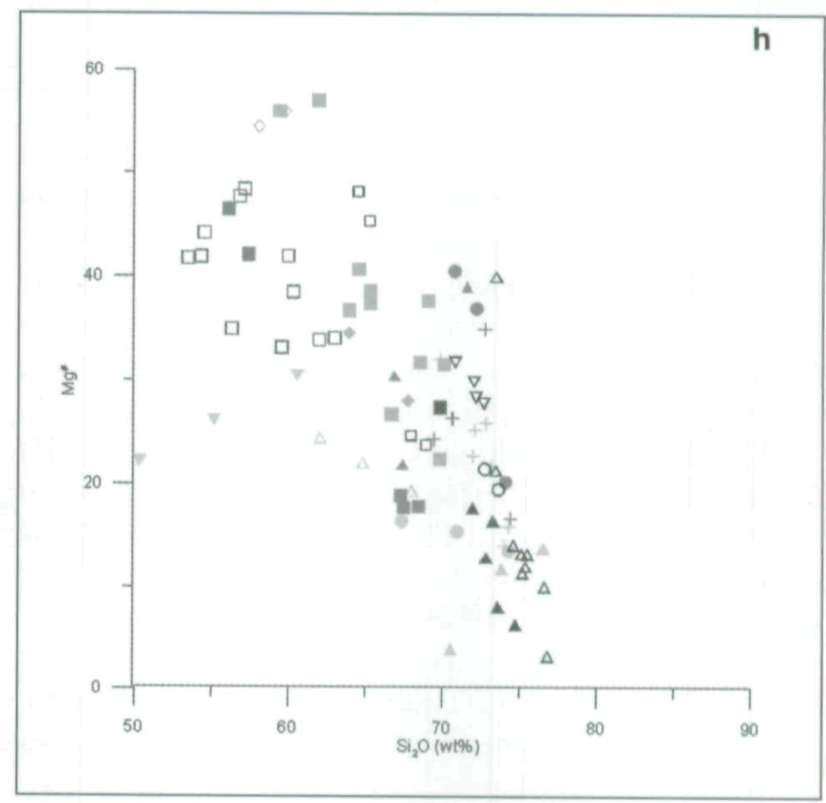

highest $\mathrm{Mg} \#$ recorded for the older suites, i.e. tonalitetrondhjemite gneiss of the GAG suite and the TG suite (Figure 9). A negative correlation exists between $\mathrm{Mg} \#$ and weight $\% \mathrm{SiO}_{2}$ for the JD granitoids.

\section{Trace and RE element composition}

A complete set of trace and REE analyses of the JD granitoids are presented in Table 5. In addition to the new dataset, selected data from the Nooitgedacht outcrop (Anhauesser, 1999) and other sites across the JD where available (Anhaeusser, 1973) (see Figure 2 for locality) were used to illustrate the trace element variation across the JD. Additionally, the average TTG and adakite (Table 6) compositions are plotted along the JD data.

The LILE concentrations (both $\mathrm{Sr}$ and $\mathrm{Ba}$ ) are high $(\sim 500 \mathrm{ppm})$ in the TG suite. These values are comparable to the average TTG suite which has been 

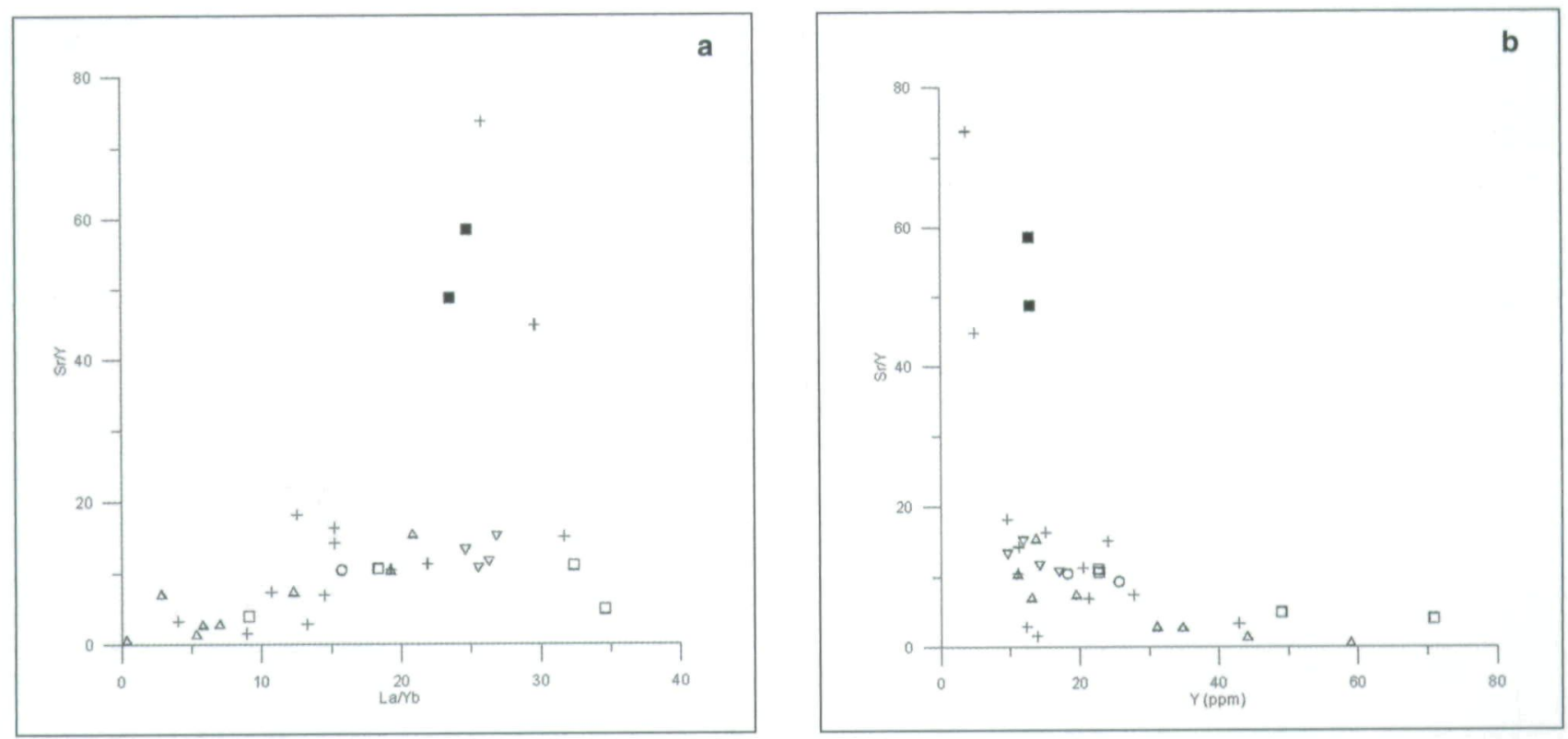

Figure 10. (a) $S r / Y$ versus La/Yb diagrams for the JD (Symbols as in Figure 9) (b) $S r / Y$ versus $Y$ diagrams for the JD (Symbols as in Figure 9).

described as having high LILE ( $\mathrm{Sr}, \mathrm{Rb}, \mathrm{Ba}$ ) contents with Sr and $\mathrm{Ba}$ both $>500 \mathrm{ppm}$. Although the GG and GAG suites have high $\mathrm{Ba}$ concentrations (200 to $500 \mathrm{ppm}$ ), the $\mathrm{Sr}$ values are generally lower, ranging between 100 and $300 \mathrm{ppm}$. The majority of the Nooitgedacht rocks do not reflect high $\mathrm{Ba}$ content; however, they do have relatively high $\mathrm{Sr}$ compositions.

The TG suite has low $\mathrm{Rb}(<100 \mathrm{ppm})$ content with $\mathrm{Rb} / \mathrm{Sr}$ ratios ranging between 0.08 and 0.12 (similar to values typical for high-Al TTG suites) (Table 5), whereas the $\mathrm{Rb} / \mathrm{Sr}$ ratio for the rest of the JD is $>0.5$. High $\mathrm{Sr}$ and low $\mathrm{Y}$ and $\mathrm{Yb}$ concentrations, and correspondingly high $\mathrm{Sr} / \mathrm{Y}$ ratios as shown by the TG suite, is characteritic of adakites and high-Al TTG suites (Table 5 and Table 6). The GAG trondhjemite-tonalite gneiss and TG suites generally show overlap in major element compositions but can be differentiated on the basis of low $\mathrm{Sr} / \mathrm{Y}$ ratio demonstrated by the GAG suite and evidenced on the $\mathrm{Sr} / \mathrm{Y}$ vs La/Yb diagram (Figure 10). Unfortunately no $\mathrm{Y}$ values were available for the Nooitgedacht rocks. Elemental ratios such as low $\mathrm{Rb} / \mathrm{Sr}(<0.15)$, elevated $\mathrm{Sr} / \mathrm{Y}$ $(>40), \quad(\mathrm{La} / \mathrm{Yb})_{\mathrm{N}}>1$ have been suggested to be characteristic of TTG suites as is evident from the TG suite and GAG suite tonalite trondhjemite gneiss (Table 5 and 6).

Harker-type variation diagrams for selected trace elements vs $\mathrm{wt} \% \mathrm{SiO}_{2}$ are given in Figure 11. In general the trace elements vs $\mathrm{wt} \% \mathrm{SiO}_{2}$ diagrams show trends that are less clearly defined compared to the major elements, although some elements do display linear distribution patterns. For instance $\mathrm{Rb}$ and $\mathrm{Pb}$ show broad positive correlations with increasing $\mathrm{SiO}_{2}$ whereas $\mathrm{Sr}, \mathrm{Cr}$ and $\mathrm{Ni}$ are negatively correlated with $\mathrm{SiO}_{2}$. The plots for $\mathrm{Ba}, \mathrm{Sr}$ and $\mathrm{Zr}$ vs $\mathrm{wt} \% \mathrm{SiO}_{2}$ demonstrate bell-shaped data arrays with two distinct groupings, ie. the older TG suite and GAG suite tonalite trondhjemite gneiss, and the GAG granodiorite/ adamellite gneiss and GG suites respectively. This indicates that these elements behaved incompatibly during the crystalisation of the protolith of the older TG suite and GAG suite tonalite trondhjemite gneiss, and compatibly during the crystalisation of the younger more felsic GAG granodiorite/adamellite gneiss and GG suites. The mafic TG suite and tonalite-trondhjemite gneiss of the GAG suite (including Nooitgedacht diorite-tonalites) is enriched in highly compatible element $(\mathrm{Cr}$ and $\mathrm{Ni}$ ) compared to the second grouping of GG granodiorite/adamellite gneiss and GAG suites.

In general, the majority of the JD granitoids displays a moderately fractionated REE pattern, illustrated by the slight LREE-enrichment $(\mathrm{La})\left((\mathrm{La} / \mathrm{Yb})_{N}=1\right.$ and 25$)$ and more or less flat HREE pattern (relative to chondritic concentrations), shown on the chondrite-nromalized REE-diagram (Figures 12a to e). The TG suite and GAG suite tonalite trondhjemite gneiss (high-MgO suites) display a stronger fractionated REE pattern (high $\mathrm{La}_{\mathrm{N}} / \mathrm{Yb}_{\mathrm{N}}$ ratios) compared to the rest of the GAG suite and the GG suite (specifically the homogenous adamellite/granodiorite), which show a depleted LREE and relatively elevated HREE pattern. Although the GAG granodiorite/adamellite gneiss and GG suites are relatively undistinguishable based on major element compositions the REE pattern differs in such a way that discrimination between these suites is possible in that the GAG suite displays a steeper pattern on the chondrite-normalised REE diagram compared to the GG suite.

The GG suite and most of the GAG suite have a strong negative $\mathrm{Eu}$ anomaly shown on the chondritenormalised REE diagram whereas the high-Mg suites, ie. TG suite and tonalite-trondhjemite gneiss of the GAG 
suite show a slight positive anomaly. The negative Eu anomaly is an indication that plagioclase fractionation probably occurred during the evolution of the younger GAG and GG suites.

The multi-element diagram show trace element variations normalised to primitive mantle values of Sun and McDonough (1989) (Figure 13). The distinctive features shared by most of the JD granitoids, as shown on the primitive mantle normalised diagram, include strong depletion in fluid-sensitive elements such as $\mathrm{Pb}$ as well as consistent negative $\mathrm{Nb}$ anomaly and a positive $\mathrm{U}$ and $\mathrm{Y}$ anomalies. However, the TG suite and some of the GAG suite tonalite-trondhjemite gneiss display an enrichment of $\mathrm{Pb}$. The strongly fractionated REE pattern, high $(\mathrm{La} / \mathrm{Yb})_{\mathrm{N}}$ ratio and depletion in HREE $(\mathrm{Yb})$ of the JD rocks are characteristics shared with modern adakites and TTG suites. The GG suite and some of the GAG suite (granodiorite to adamellite gneiss) rocks display a strong negative anomaly for $\mathrm{Sr}$ and $\mathrm{Eu}$. In contrast the TG suite shows a strong positive $\mathrm{Sr}$ and the absence of a Eu anomaly. The pattern exhibited by the GAG suite differs from the rest of the JD rocks in that there is "fanning" at the HREE end of the diagrams.

Discrimination diagrams, distinguishing between and comparing various granitic rocks and their tectonic environments, have become a fundamental part of any granitoid study. According to some studies (Twist and Harmer, 1987; Arculus, 1987; Clarke, 1992; Roberts and Clemmens, 1993) caution should be taken in the use of trace element tectonic discrimination diagrams using $\mathrm{Rb}$ and even $\mathrm{Y}+\mathrm{Nb}$ due to the influence of source rock composition and the generative processes on the chemistry. Furthermore these diagrams show the setting in which the protoliths were formed rather than the tectonic setting when the granitoid magmas were produced.

Despite this concern the trace element discrimination procedures suggested by Pearce et al. (1984), the elements $\mathrm{Rb}, \mathrm{Y}$ and $\mathrm{Nb}$ the $\mathrm{Nb}$ versus $\mathrm{Y}$, for intrusive rocks is widely used and therefore employed in the present study to indicate the probable tectonic settings of the JD granitoids. The majority of the JD granotoids cluster in the VAG (Volcanic Arc Granite) + syn-COLG (syn-collisional Granite) and WPG (Within Plate Granite) field on the $\mathrm{Nb}$ versus $\mathrm{Y}$ diagram (Figure 14a). Further discrimination between these fields is shown by the $\mathrm{Rb}$ versus $\mathrm{Y}+\mathrm{Nb}$ diagram, which points to a VAG tectonic environment for the majority of the JD granitoids (Figure 14b). From these diagrams it is proposed that the formation of JD granitoids in an Oceanic Ridge environment can be ruled out.

\section{Interpretation and discussion Comparison of JD with other TTG}

The majority of the TG suite, GAG suite tonalitetrondhjemite gneiss as well as the Nooitgedacht rocks show major element characteristics similar to high-Mg adakites and typical TTG suites such as the Barberton plutons (Nelspruit, Kaap Valley and Nelshoogte),
Superior Province, Pilbara Craton, Dharwar Craton and Zimbabwe Craton, which are generally siliceous $\left(\mathrm{SiO}_{2} \sim 70\right.$ weight $\left.\%\right)$, aluminous $\left(\mathrm{Al}_{2} \mathrm{O}_{3} \sim 15\right.$ weight \%), with high $\mathrm{Na}_{2} \mathrm{O}$ (3 to 7 weight \%) and is marked by a high $\mathrm{Na}_{2} \mathrm{O} / \mathrm{K}_{2} \mathrm{O}(>1)$ ratio. Furthermore the high $\mathrm{MgO}>5$ weight $\%, \mathrm{FeO}, \mathrm{Mg} \#, \mathrm{Cr}$ and $\mathrm{Ni}$ contents shown by the TG suite, GAG suite tonalite-trondhjemite gneiss as well as the Nooitgedacht rocks are characteristic of high- $\mathrm{Mg}$ adakite (sanukitoid) and high-Mg diorites such as those described from the Barberton TTG suites, Pilbara high$\mathrm{Mg}$ diorite and melanodiorite and Superior Province high-Mg diorite.

The TG and GAG suites to some extent reflect the high LILE ( $\mathrm{Sr}, \mathrm{Rb}, \mathrm{Ba}$ ) contents characteristic to TTG suites although the $\mathrm{Sr}$ and $\mathrm{Ba}$ content is slightly lower than typically expected for TTG suites. The high Ba, Sr and the slightly less elevated $\mathrm{Rb}$ trend exhibited by the TG and GAG suites is similar to that observed for TTG's from Vredefort, Barberton, the high Mg-diorites of the Superior Province and Pilbara Craton as well as for Closepet granite. The TG and GAG suites show a fractionated REE pattern (higher $\mathrm{La}_{\mathrm{N}} / \mathrm{Yb}_{\mathrm{N}}$ ratios), a characteristic generally shared by modern adakites and TTGs. However, the JD granitoids show a relatively flat REE pattern, suggesting no garnet fractionation. The TG suite and tonalite-trondhjemite gneiss of the GAG suite have high $\mathrm{Sr} / \mathrm{Y}$ and high $\mathrm{La} / \mathrm{Yb}$ ratios, a characteristic shared by adakites, TTG suites and high Mg-diorites such as Barberton Mountain Land and high Mg-diorites of the Superior Province and Pilbara Craton.

\section{The role of fractional/partial melting in creating observed chemical variations}

The high $\mathrm{Ni}$ and $\mathrm{Cr}$ content together with the high $\mathrm{Mg} \#$ of TTG suites are considered an indication of interaction with the mantle wedge (Smithies and Champion, 2000). Partial melts of hydrated mantle were shown to contain a high $\mathrm{Ni}$, Co and $\mathrm{Cr}$ concentration, which can be attributed to the high concentrations of these elements in the source region combined with a high degree of melting rather than partial melting of garnet-amphibolite or eclogite, which are both depleted in these elements (Kleinhans et al., 2003). Partial melts from garnetamphibolite and eclogite would be even more depleted in these elements and could only acquire elevated $\mathrm{Ni}$, $\mathrm{Co}$ and $\mathrm{Cr}$ contents through assimilation of peridotite. This is however, not supported by the trace element characteristics of TTG suites. High LILE concentrations are considered an indication of crustal contamination of magmas (Martin et al., 2005).

The GAG (granodiorite to adamellite gneiss) and GG suites display a strong negative anomaly for $\mathrm{Sr}$ and $\mathrm{Eu}$, typical of a GGM suite, whereas the TG suite shows a strong positive $\mathrm{Sr}$ and the absence of a Eu anomaly, typical of TTG suites, adakite, high-Mg diorite/ sanukitoid. The negative Eu anomaly and the absence of a positive Sr anomaly for the GAG and GG suites could reflect the presence of plagioclase in the source. The negative $\mathrm{Eu}$ anomaly is an indication that 

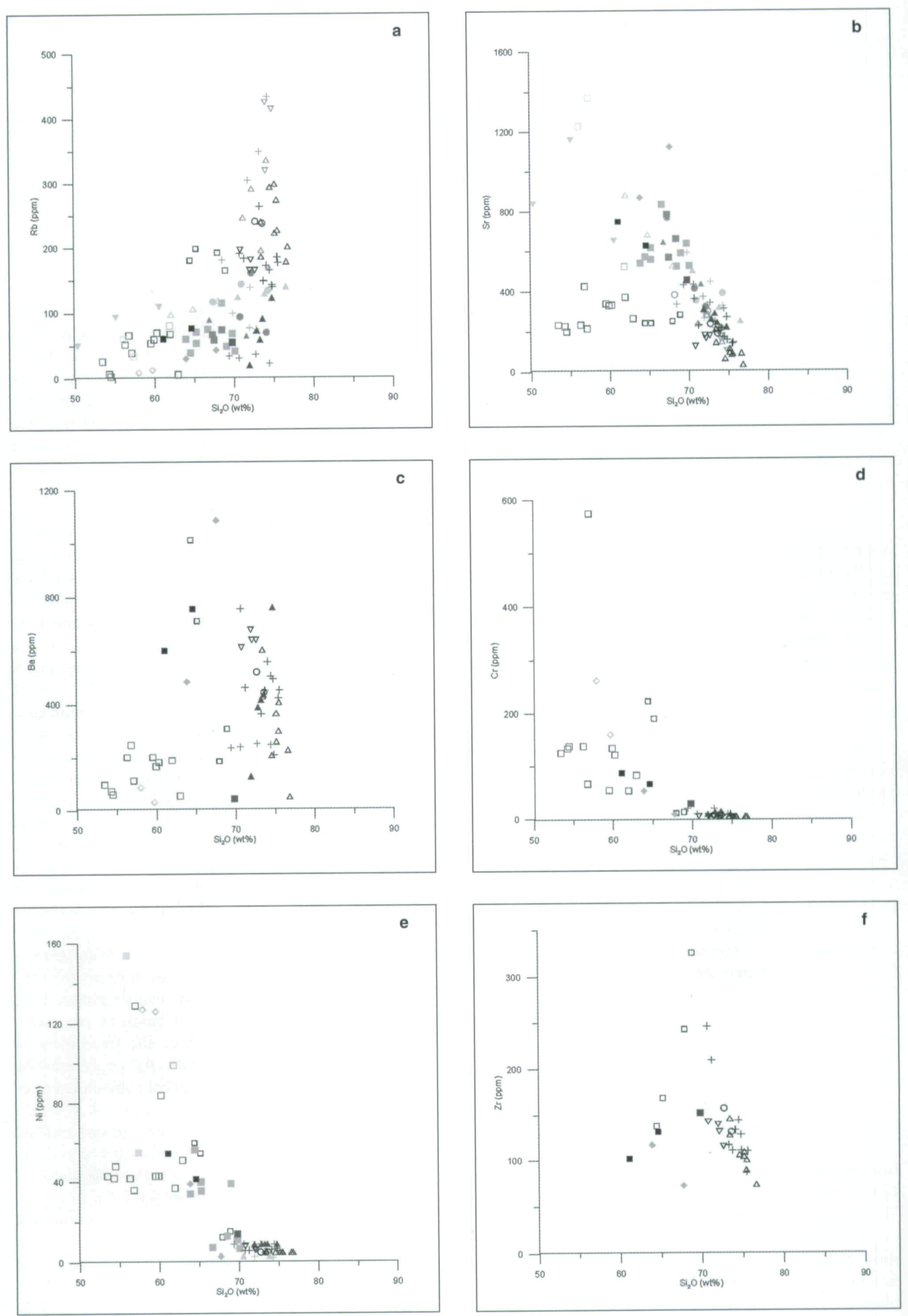

SOUTH AFRICAN JOURNAL OF GEOLOGY 


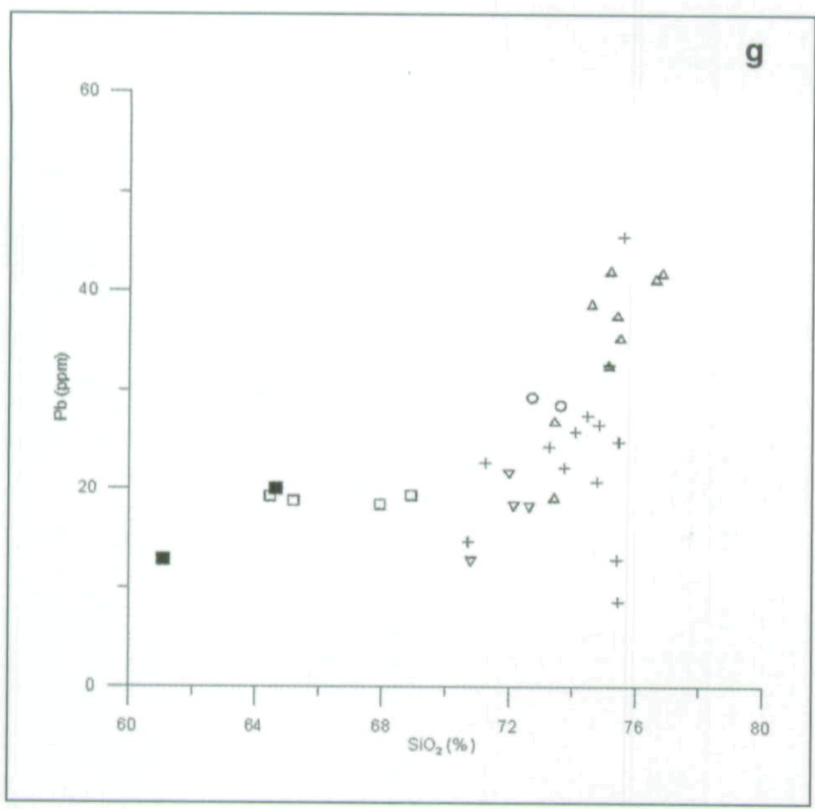

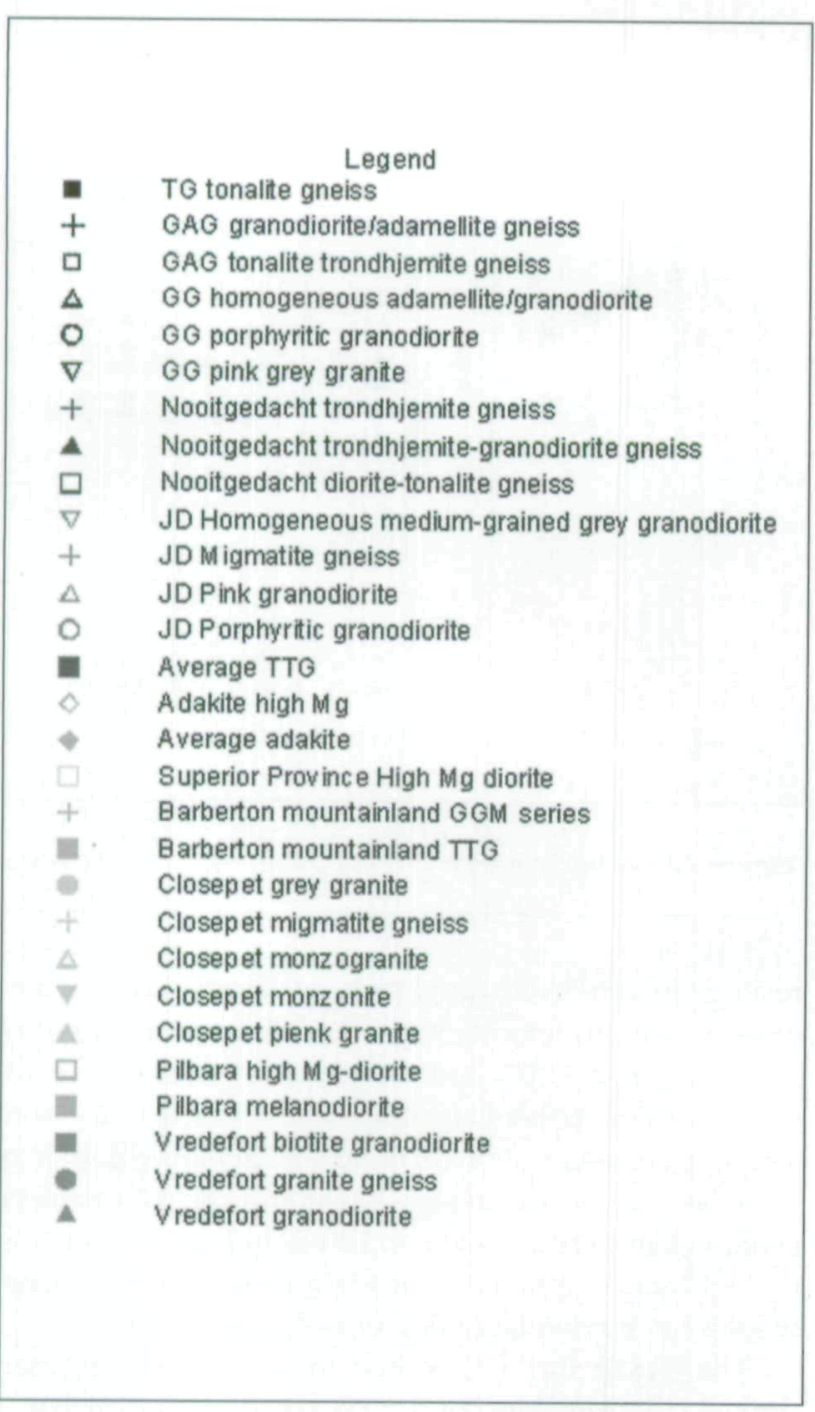

Figure 11. Trace element Harker variation diagrams for the JD granitoids. Also included are data from previous studies (including average TTG, average adakite and average bigh Mg adakite. plagioclase fractionation probably occurred during the evolution of the GAG and GG suites. The negative Sr anomaly recorded in the calc-alkaline GGM suites and the GAG (granodiorite to adamellite gneiss) and GG suites therefore suggests these JD rocks did undergo some plagioclase fractionation. Furthermore the HFSE depletion and distinct enrichment of fluid sensitive elements such as $\mathrm{Pb}$, observed in all three HHD granitoid suites, are generally considered to indicate an arc signature. This signature of the fluid mobile elements can not easily be reconciled with direct melting of oceanic crust.

\section{Discussion of likely tectonic setting, peterogenesis}

High-Mg diorites are considered to be relatively scarce ( $<5 \%$ of all Archaean TTGs) with very few, if any, pre-3 $000 \mathrm{Ma}$ TTG suites showing this trend. The scarcity of high-Mg diorites suggests that the conditions for formation were not met in all Archaean terranes. The recognition of high-Mg diorites on the JD is therefore noteworthy as it signifies that the conditions necessary for high-Mg diorite formation were met during the formation of the TG suite, which is present in a limited area along the southern edge of the JD (and Nooitgedacht outcrop in the centre of the JD). The TG suite most probably formed through melting of a subducted oceanic slab, rather than underplated basalt, with the melt interacting with mantle peridotite during its accent through a thin mantle wedge.

Compared to the average TTG suite a typical GGM suite, such as the Barberton plutons (Dalmein, Mpageni, Nelspruit), has high $\mathrm{SiO}_{2}(>70 \mathrm{wt} \%)$ and $\mathrm{K}_{2} \mathrm{O}$ (3 to 5 wt $\%)$, low $\mathrm{Na}_{2} \mathrm{O} / \mathrm{K}_{2} \mathrm{O}(<1)$ ratios and lower $\mathrm{Al}_{2} \mathrm{O}_{3}$ contents. The majority of the GAG and GG suite share these characteristics. GGM suites are characteristically richer in HREE compared to typical TTG suites. The high $\mathrm{La} / \mathrm{Yb}$ and $\mathrm{Sr} / \mathrm{Y}$ ratios of TTG suites are thought to be the result of partial melting of an eclogitic basaltic crust. High $\mathrm{Sr}$ and low $\mathrm{Y}$ concentrations, with the corresponding high $\mathrm{Sr} / \mathrm{Y}$ ratios are characteristics defining adakites and considered an indication of their origin as slab-melt under high pressure (Defant and Drummond, 1990).

TTG suites and GGM suites have strong similarities such as over enrichment in fluid sensitive elements such as $\mathrm{Pb}$ (Martin, 1994; Kleinhans et al., 2003). Kleinhans et al. (2003) suggested the characteristic features of TTG's include HFSE depletion and distinct $\mathrm{Pb}$ enrichment signature seen on the chondrite-normalised REE diagram, as reflected in all JD suites, is evidence that these rocks are derived from refertilised mantle above subducion zones.

HREE depletion can be explained by three approaches i.e. the melting of garnet-amphibolite eclogite in the slab or lower crust, inherited REE pattern of the slab derived fluid or by fractional crystallization of garnet/amphibole in hydrous mantle melts. The last two suggest TTG originate from hydrated mantle melts with LREE preferentially transferred to mantle wedge and HREE 

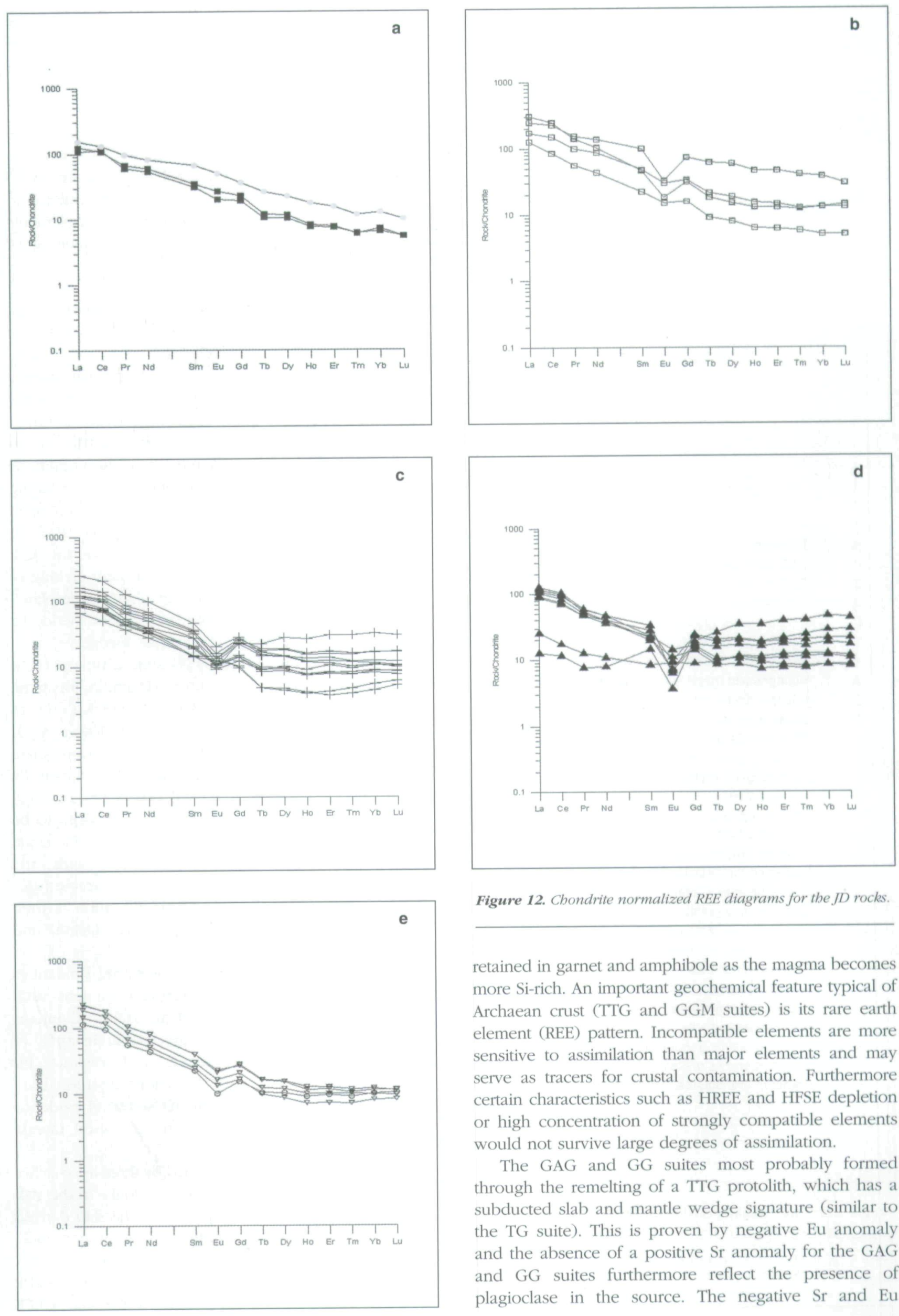

Figure 12. Chondrite normalized REE diagrams for the JD rocks.

retained in garnet and amphibole as the magma becomes more Si-rich. An important geochemical feature typical of Archaean crust (TTG and GGM suites) is its rare earth element (REE) pattern. Incompatible elements are more sensitive to assimilation than major elements and may serve as tracers for crustal contamination. Furthermore certain characteristics such as HREE and HFSE depletion or high concentration of strongly compatible elements would not survive large degrees of assimilation.

The GAG and GG suites most probably formed through the remelting of a TTG protolith, which has a subducted slab and mantle wedge signature (similar to the TG suite). This is proven by negative Eu anomaly and the absence of a positive Sr anomaly for the GAG and GG suites furthermore reflect the presence of plagioclase in the source. The negative $\mathrm{Sr}$ and $\mathrm{Eu}$ 

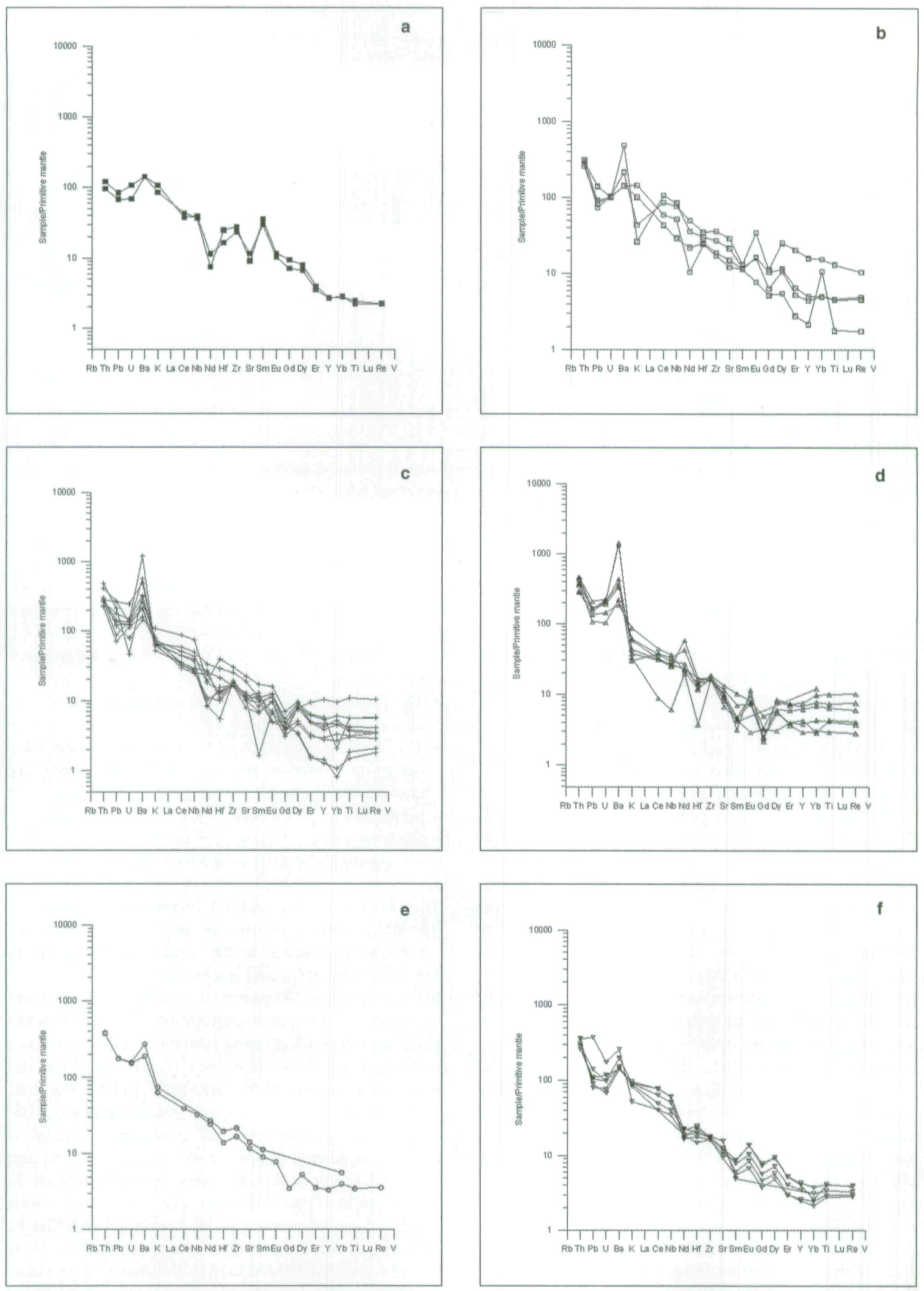

Figure 13. Primitive mantle normalized Spider diagrams for ID rocks. Normalizing values are those from Sun and McDonough (1989). 

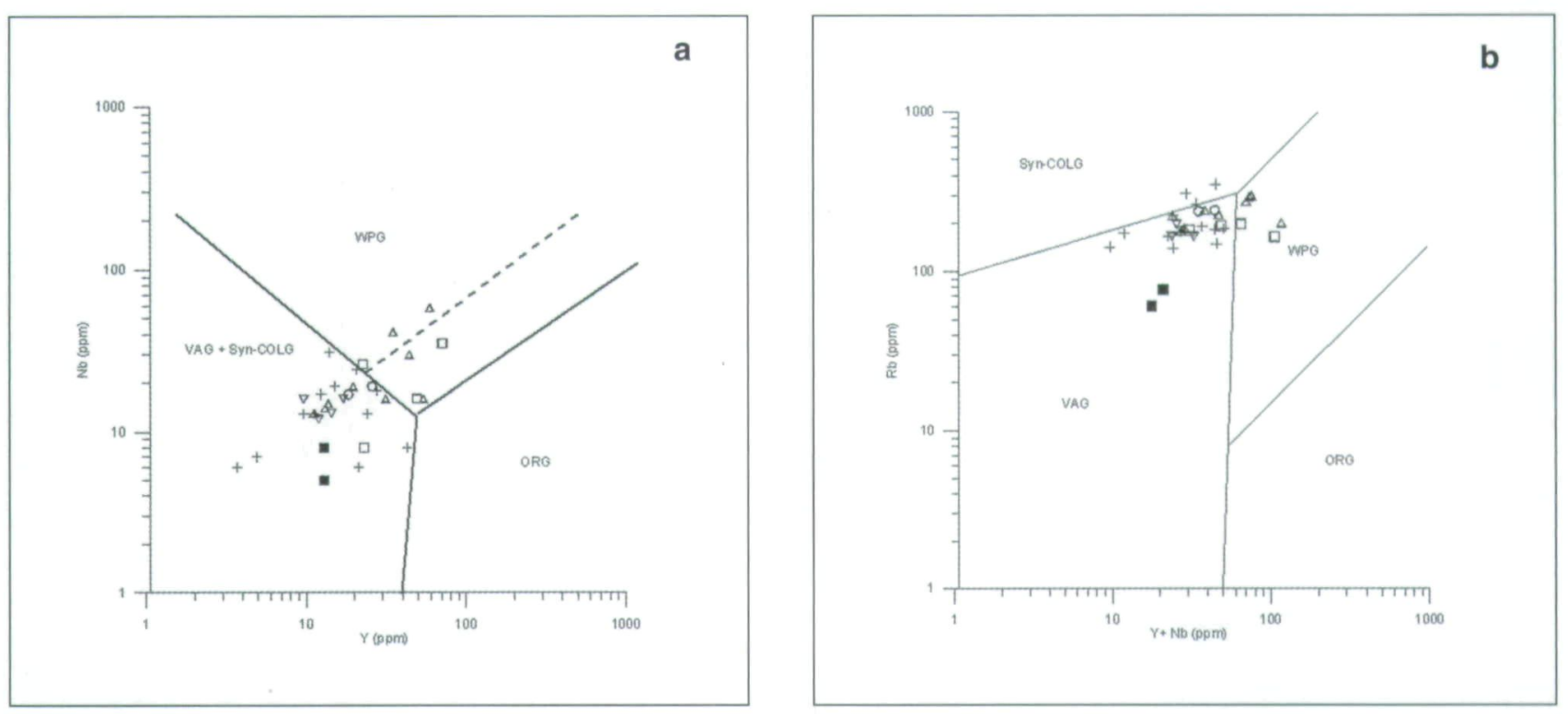

Figure 14. (a) Nb-Y diagram showing a volcanic arc (VAG) and syn-collision (Syn-COLG) tectonic setting for the majority of the JD granitoids (symbols as above), (b) Rb vs Y+Nb diagram showing a predominantly volcanic arc (VAG) tectonic setting for the JD granitoids. (VAG =volcanic arc granite, $S y n-C O L G=$ syn-collision granite, $W P G=$ within plate granite, $O R G=$ oceanic ridge granite).

anomalies and enriched $\mathrm{Pb}$ and depleted HFS elements may also be the result of partial melting of a basaltic source without the need for plagioclase fractionation.

Disequilibrium textures, such as discontinuous rims on plagioclase/ K-feldspar contacts, reaction rims, coronas, overgrowths and zonations, observed in the granitoids of the JD suggest crystal-fluid interaction occurred at various stages during their formation. Furthermore the coronas of secondary titanite developed around magnetite and ilmenite grains are evidence that the JD has gone through a pervasive metasomatic phase. The deuteric alteration and likely late stage interaction between the magma and the host rock of the JD rocks can be expected to have had some impact on the mobile elements $(\mathrm{K}, \mathrm{Rb}, \mathrm{Sr}, \mathrm{Ba}$ and $\mathrm{Na})$. These elements are mainly associated with leachable minerals such as feldspars and micas. The slight difference in mineral proportions of JD TTG's, identified through the geochemical investigation, and typical TTG suites can therefore possibly be attributed to the alteration process and late stage interaction between the magma and the host rock. The slight inconsistency seen in the classification diagram (Figure 8) where rocks with field labels "tonalite" plot as granodiorite is possibly an artefact of the widespread alteration. Barton et al. (1999) also showed that the deuteric alteration of the feldspars affected the Rb-Sr whole rock system.

\section{Conclusion}

The macro and microscopic investigation of the JD showed that this window of Archaean rock consists of a mosaic of granitoids manifest by the differences in areal extent, mineralogy, texture, composition and age. Due to poor exposure the contact relationships between the various granitoids could not be confirmed. Based on the microscopic and geochemical investigation the JD granitoids could be subdivided into three main suites:

- The Tonalitic Gneiss suite (TG) around the southern boundary;

- The Granodiorite to Adamellite Gneiss suite (GAG) across the northern part;

- The Granodiorite/adamellite to Granite suite (GG) occurring between the TG and GAG suites and consisting of;

- porphyritic granodiorite;

- medium-grained pinkish-grey granite;

- homogeneous adamellite/granodiorite.

The new major, trace and REE element data from across the JD provide confirmation that the JD granitoids represent TTG suites at the centre of the Kaapvaal Craton. Petrography and geochemistry is in agreement that the Archaean JD granitoids can be subdivided into a tonalite-trondhjemite-granodiorite or GGM series (GG suite and trondhjemites of the GAG suite) and a high Mg-diorite series (tonalities TG suites and tonalitetrondhjemite gneiss of the GAG suite and Nooitgedacht diorite-tonalite). Similarities exist between the composition of the GG and trondhjemite gneiss of the GAG suite with plutonic rocks in the Barberton area and Vredefort structure. The geochronological study by Barton et al. (1999) showed that these rocks were emplaced coeval and may be genetically related. The TG suite represents high-Mg diorites similar to those described for the Pilbara Craton and Superior Province.

In this paper, sanukitoid (high-Mg diorite) rocks are documented for the first time in the Archaean of the central Kaapvaal Craton. 
The high $\mathrm{Mg} \#$, $\mathrm{Ni}$ and $\mathrm{Cr}$ as well as enrichment in $\mathrm{Pb}$ and HFSE depletion of TG suite suggests that it is unavoidable that these rocks were derived from melts which were in contact with the mantle wedge in a subduction environment.

The most appropriate model for the formation of the TG suite is that of subduction of an oceanic slab and the interaction with the mantle wedge. The presence of restite phases (such as plagioclase cores) and approximate TTG geochemistry in the GAG and GG suites suggests that it is most likely that these rocks were derived from remelting of a TTG protolith. This is supported by the proposed cogenetic formation from a 3300 to $3500 \mathrm{Ma}$ source proposed by Barton et al. (1999). The most appropriate model for the formation of the GAG and GG suites are the partial melting of a TTG protolith with a subducted slab and mantle wedge signature (similar to the TG suite). However, the absence in strong enrichment in $\mathrm{Pb}$, which normally show mantle wedge enrichment by slab fluids suggest an alternative setting and can not rule out formation through foundering of lower crust or mantle pluming.

Although not part of this investigation, previous data from rocks of the Nooitgedacht exposure were evaluated along with the current JD data. It can be concluded that the rocks from this exposure show some differences in the geochemistry when compared to the rest of the JD. Extrapolation of a petrogenic model for the entire JD based solely on this outcrop should therefore be considered with care. Prevec et al. (2004) suggested that the derivation of the TTG-dyke package from the Nooitgedacht outcrop at c. $3120 \mathrm{Myr}$ can be inferred to involve partial melting of an eclogitic (garnetiferous) lower crust, probably related to basaltproducing partial melting of the mantle.

\section{Acknowledgements}

The Council for Geoscience is thanked for their support in analysing the samples. Professor S.A. de Waal is thanked for his valuable comments and review of the manuscript. The authors would also like to thank Dr. Armin Zeh as well as an anonymous reviewer and the editor Professor Jay Barton for their constructive comments, which helped to improve the manuscript.

\section{References}

Allsopp, H.L., (1961). Rb-Sr age measurements on the total rock and separated mineral fractions from the old granite of the central Transvaal. Journal of Geophysical Research,66, 1499-1508.

Anhaeusser, C.R., (1973). The geology and geochemistry of the Archaean granites and gneisses of the Johannesburg-Pretoria dome. In: L.A. Lister, (Editor), Symposium on the granites, gneisses and related rocks. Special Publication Geological Society South Africa, 3, 361-385.

Anhauesser, C.R., (1977). Geological and geochemical investigation of the Roodekrans ultramafic complex and surrounding Archaean volcanic rocks, Krugersdorp District. Transactions of Geological Society South Africa, 80, 17-28.

Anhauesser, C.R., (1978). The geology and geochemistry of the Muldersdrift Complex and surrounding area, Krugersdorp District. Transactions of Geological Society South Africa, 81, 193-203.
Anhauesser, C.R., (1992). Archaean granite-greenstone relationships on the farm Zandspruit 191 IQ, North Riding area, Johannesburg Dome. South Africa Journal of Geology, 95, 94-101

Anhauesser, C.R., (1999). Archaean crustal evolution of the central Kaapvaal Craton, South Africa: Evidence from the Johannesburg Dome. South Africa Journal of Geology, 102, 303-322.

Anhauesser, C.R., (2004). Arc related TTG magmatism and oceanic crust on the Johannesburg Dome: Remnants of an Archaean basement suture flanking the Witwatersrand basin. GeoScience Africa Conference 2004, Abstracts Volume, University of the Witwatersrand, Johannesburg, South Africa, 18-19. ISBN no. 0-620-32470-8

Anhaeusser, C.R. and Burger, A.J., (1982). An interpretation of U-Pb zircon ages for Archaean tonalite gneisses from the Johannesburg-Pretoria Dome. Transactions of Geological Society South Africa, 85, 111-116.

Arculus, R.J., (1987). The significance of source versus process in the tectonic controls of magma genesis. Journal of Volcanology and Geothermal Research, 32, 1-12.

Arth, J.G., Hanson, G.N., (1975). Geochemsitry and origin of the early Precambrian crust of northern Minnesota. Geochim. Cosmochim. Acta. 39, 325-362.

Barton, J.M. and Van Reenen, D.D., (1992). When was the Limpopo orogeny? Precambrian Research, 55, 7-16.

Barton, J.M., Barton, E.S. and Kröner, A., (1999). Age and isotopic evidence for the origin of the Archaean granitoid intrusives of the Johannesburg Dome, South Africa. Journal of African Earth Science, 28, 3, 693-702p.

Bedard, J.H., Brouillette, P., Madore, L., Berclaz, A., (2003). Archaean cratonization and deformation in the northern Superior Province, Canada: an evolution of plate tectonic versus vertical tectonic models. Precambrian Research, 127, 61-87.

Blewett, R.S., (2002). Archaean tectonic processes: a case for horizontal shortening in the Northern Pilbara granite-greenstone terrane, Western Australia. Precambrian Research, 113, 87-120.

Burger, A.J. and Walraven, F., (1979). Summary of age determinations carried out during the period April 1977 to March 1978. Annals. Geologicla Survey of South Africa, 12, 209-218.

Brandl, G., De Wit, M.J., (1997). The Kaapvaal Craton. In M.J. De Wit and L.D. Ashwal (Editors.) Greenstone Belts. Oxford: Oxford University Press, 581-607.

Champion, D.C., Smithies, R.H., (2000). The geochemistry of the Yule Granitoid Complex, Eastern Plibara Granite-Greenstone Terrane: evidence for felsic crust. Annual Report of Western Australia Geological Survey, 1999-2000, 42-48.

Charlesworth, E.G., McCarthy, T.S., (1990). Structural aspects of the eastern part of the Rietfontein fault system. South African Journal of Geology, 93, 211-223.

Chapell, B.W., White, A.J.R., (1974). Two contrasting granite types. Pacific Geology, 8, 173-174.

Clarke, D.B., (1992). Granitoid Rocks. Chapman and Hall, London, 281 pp.

Cloete, H.C.C., Truter, J., 2001. Major and trace element analysis by X-ray Fluorescence Spectrometry at the Council for Geoscience. Open File no. 2001-0074.

Condie, K.C., (1981). Archaean Greenstone Belts, Development in Precambrian Geology 3. Elsevier, Amsterdam, 434pp.

Condie, K.C., (2005). TTGs and adakites: are they both slab melts ? Lithos, $80,33-44$

Cornell, D.H., Armstrong, R.A. and Walraven, F., (1998). Geochronology of the Proterozoic Hartley Basalt Formation, South Africa: constraints on the Kheis tectogenesis and the Kaapvaal Craton's earliest Wilson cycle. Journal of African Earth Sciences, 26, 5-27.

Corstophine, G.S., Jorrisen, E., (1908). The Stratigraphy of Zwartkop 82. Transcations of the Geological Society of South Africa, 11, 55-68.

Debon, F., Le Fort, P., (1982), A chemical-mineralogical classification of common plutonic rock associations. Transactions of the Royal Society of Edinburgh: Earth Sciences, 73, 135-149.

Defant, M.J., Drummond, M.S., (1990). Derivation of some modern arc magmas by melting of young subducted lithosphere. Nature, 374, 662-665.

De Witt, M.J., Roering, C., Hart, R.J., Armstrong, R.A., De Ronde, C.E.J., Green, R.W.E., Tredoux, M., Peberdy, E. and Hart, R.A., (1992), Formation 
of an Archaean continent. Nature, 357, 553-562.

De Wit, M.J., 1998. On Archaean granites, greenstones, cratons and tectonics, does the evidence demand a verdict? Precambrian Research, 91, 181-226 Droop, G.T.R., (1987). A general equation for estimating $\mathrm{Fe}^{3+}$ concentrations in ferromagnesian silicates and oxides from microprobe analyses, using stoichiometry criteria. Mineralogical Magazine, 51, 431-435.

Duncumb, P. and Reed, S.J.B., (1968). The calculation of stopping power and backscatter effects in electron probe micro-analysis. National Bureau of Standards, U.S. Department of Commerce, Special Publication 298, 135-154.

Eglington, B.M., Armstrong, R.A., (2004). The Kaapvaal Craton and adjacent orogens, southern Africa: a geochronological database and overview of the geological development of the craton. South African Journal of Geology, 107, 13-32.

Evans, O.C. and Hanson, G.N., (1997). Late- to Post-Kinematic Archaean Granitoids of the S.W. Superior Province: Derivation through Direct Mantle Mixing. In: J.M. De Wit and L.D. Ashwal (Editors.), Greenstone Belts. Oxford: Oxford University Press,

Gibson, R.L., Reimold, W.U., (2001). The Vredefort impact structure, South Africa. The Scientific evidence and a two-day excursion guide. Memoirs of the Council for Geoscience, 92, 111pp.

Hartnady, C., Joubert, P., Stowe, C., (1985). Proterozoic crustal evolution in southwestern Africa. Episodes, 8, 236-244.

Hilliard, P., (1994). The structural evolution of the Johannesburg Dome, Kaapvaal Craton, South Africa. M.Sc. thesis (unpubl.) University of Pretoria, 99pp.

Hilliard, P. and McCourt, S., (1995). Bedding-parallel simple shear deformation in the West Rand Group rocks on Northcliff Promotory, Johannesburg, South Africa- insight into the Late Archaean evolution of the Kaapvaal Craton. South African Journal of Geology, 98, 349-355pp

Heinrich, K.FJ., (1968). Advances in X-ray micro-analysis. Vol 11 Plenum Press New York. 287pp

Hutchinson, C., (1974). Laboratory handbook of petrographic techniques, Wiley-Interscience, New York, 527pp.

Jahn, B.M.; Glikson, A.Y; Peucat, J.J. and Hickman, A.H., (1981). REE geochemistry and isotopic data of Archaean silicic volcanics and granitoids from the Pilbara Block, western Australia: implications for early earth crustal evolution. Geochim Cosmochim Acta, 45, 1633-1652.

Jarosewich E., Nelen J.A. and Norberg J.A., (1980). Reference standards for electron microprobe analysis, Geostandards Newsletter 4, 43-47.

Johnson, A.D., Wyllie, P.J., (1988). Constraints on the origin of Archaean trondhjemites based on phase relationships of Nuk Gneiss with $\mathrm{H}_{2} \mathrm{O}$ at 15kbar. Contributions to Mineralogy and Petrology, 100, 35-46.

Jordaan, L.J., Maritz, H. and Lehaha, M.T., (2005). Quantitative ICP-MS Analysis of Rare Earth Elements in Rock Samples. Council for Geoscience, Pretoria, South Africa. Open File Report, No. 2004-0205.

Kleinhans, I.C., Kramers, J.D. and Kamber, B.S., (2003). Importance of water for Archaean granitoid petrology: a comparative study of TTG and potassic granitoids from Barberton Mountain Land, South Africa. Contribution to Mineralogy and Petrology, 145, 377-389.

Koma, S.L., Reimold, W.U., Krogh, T.E., Colliston, W.P., (1996). A $2.023 \mathrm{Ga}$ age for the Vredefort impact event and a first report of shock metamorphosed zircons in pseudotachylitic breccias and granophyre Earth and Planetary Science Letters, 144, 369-388.

Kretz, R., (1983). Symbols for rock-forming minerals. American Mineralogist, 68, 277-279

Kruger, FJ., Cawthorn, R.G. Walsh, K.L., (1987). Strontium isotopic evidence against magma addition in the Upper Zone of the Bushveld Complex. Earth Planetary Science Letters, 84, 51-58.

Kusky, T.M., (1998). Tectonic setting and terrane accretion of the Archean Zimbabwe craton. Geology, 26, 163-166.

Leake, B.E., (1974). Nomenclature of amphiboles. Canadian Mineralogist, $16,501-520$

Lowe, D.R., (1994). Accretionary history of the Archaean Barberton greenstone belt (3.53-3.22Ga), Southern Africa. Geology, 22, 1099-1102

Martin, H., (1986). Effect of steeper Archaean geothermal gradient on geochemistry of subduction zone magmas. Geology, 14, 753-756.

Martin, H., (1987). Petrogenesis of Archaean trondhjemites, tonalities and granodiorites from eastern Finland: major and trace element geochemistry. Journal of Petrology, 28, 921-953.
Martin, H., (1994). The Archaean grey gneisses of the continental crust. In: K.C. Condie (Editor), The Archaean crustal evolution, developments in Precambrian Geology. Elsevier, Amsterdam, 205-259.

Martin, H., (1999). Adakitic magmas: modern analogues of Archaean granitoids. Lithos, 46, 411-429.

Martin, H., Smithies, R.H., Rapp, R., Moyen, J.-F., and Champion, D., (2005) An overview of adakite, tonalite-trondhjemite-granodiorite (TTG), anc sanukitoid: relationships and some implications for crustal evolution. Lithos, 79, 1-24

McCarthy, T.S., Cadle, A.B., Horrocks, P.S., (1982). Thrust faulting in the Witwatersrand rocks at Langerman's Kop, Johannesburg. Transactions of the Geological Society of South Africa, 85, 189-201

McCarthy, T.S., Charlesworth, E.G., Stranistreet, I.G., (1986). Post-Transvaal structureal features of the Northern portion of the Witwatersrand Basin. Transactions of the Geological Society of South Africa, 89, 311-323.

McCarthy, T.S., Stranistreet, I.G., Cadle, A.B., Durrheim, R., (1990). The geology of the Ventersdorp Supergroup (Bezuidenhout Valley) outlier to the east of Johannesburg and its relevance to the tectonics of a Witwatersrand Basin margin. South African Journal of Geology, 93, 289-309.

Moorbath, S., (1975). Evolution of Precambrian crust from strontium evidence. Nature, 254, 395-398.

Moyen, J.-F., Martin, H., Jayananda, M., (2001), Multi-element geochemical modeling of crust-mantle interaction during late-Archaean crustal growth The Closepet granie (South India). Precambrian Research, 112, 87-105.

Moyen, J.-F., Martin, H., Stevens, G., (2004). Where are the TTG formed? A review of geochemical and experimental data. GeoScience Africa Conference 2004, Abstracts Volume, University of the Witwatersrand, Johannesburg, South Africa, 475-476. ISBN no. 0-620-32470-8

Moyen, J.-F., Martin, H., Jayananda, M., Auvray, B., (2003). Late Archaean granites: a typology based on the Dharwar Craton (India). Precambrian Research, 127, 103-123.

Pearce, J.A., Harris, N.B.W. And Tindle, A.G., (1984). Trace element discrimination diagrams for the tectonic interpetation of granitic rocks. Journal of Petrology, 45, 956-983

Peccerillo, A., Taylor, S.R., (1976). Geochemsitry of Eocene calc-alkaline volcanic rocks from Kastamonu area, Turkey. Contributions to Mineralogy and Petrology, 58, 6-81.

Philibert, J., (1963). A method for calculating the absorption correction in electron probe microanalysis. In Proceedings Third International Congress on X-ray optics and X-ray Micro-analysis, Academic Press, New York, 379pp.

Poujol, M., Anhaeusser, C.R., (1999). The Johannesburg Dome, Kaapvaal Craton, South Africa, revisited in the light of new U-Pb single zircon dating. Infrom Circ. Econ. Res. Unit, University of the Witwatersrand, Johannesburg, South. Africa, 339, 15pp

Poujol, M. and Anhaeusser, C. R. (2001). The Johannesburg Dome, South Africa: new single zircon U-Pb isotopic evidence for early Archaean granite-greenstone development within the central Kaapvaal Craton. Precambrian Research, 108, 139-157.

Poujol, M., Anhaeusser, C.R., Gericke, B., (2003). A review of the geochronological constraints on the evolution of the Kaapvaal Craton, South Africa. Precambrian Research, 127, 181-213.

Preveca, S., Anhaeusser, C.R., Poujol, M., (2004). Evidence for Archaean lamprophyre from the Kaapvaal Craton, South Africa, South African Journal of Science 100, 549-555.

Reed, S.J.B., (1965). Characteristic fluorescence corrections in electron probe micro-analysis. British Journal of Applied Physics, 16, 913pp.

Robb, L.J., Brandl, G., Anhaeusser, C.R., Poujol, M. (2008). Archaean Granitoid Intrusions. In M.R. Johnson, C.R. Anhaeusser, R.J. Thomas, (Editors). The Geology of South Africa. 81-83

Roberts, M.P., Clemmens, J.C., (1993), Origin of High-potassium, calcalkaline I-type granitoids. Geology, 21, 825-828.

Roering, C., (1986). Aspects of thrust faulting in the northern margin of the Witwatersrand basin. Geocongress ' 86 Geological Society South Africa Johannesburg, 59-62.

Shirey, S.B., Hanson, E.N., (1984). Mantle-derived Archaean monzodiorites and trachyandesites. Nature, 310, 222-224.

Shau, Y.H., Yang, H. Y., Peacor, D.R., (1991). On oriented titanite and rutile inclusions in sagenitic biotite. American Mineralogist, 76, 1205-1217. 
Smithies, R.H., Champion, D.C., (1999). Archaean high-Mg diorites (sanukitoid) suite, Pilbara Craton, Western Australia. In: B. Barbarin (Editor), The Origin of granites and related rocks: Fourth Hutton Symposium Abstracts, September 1999. Clermont Ferrand, France, 190pp. Smithies, R.H., (2000). The Archaean tonalite-trondhjemite-granodiorite (TTG) series is not an analogue of Cenozoic adakite. Earth and Planetary Science Letters, 182, 115-125.

Smithies, R.H., Champion, D.C., (2000). The Archaean High-Mg diorite suite: Links to Tonalite-Trondhjemite-Granodiorite Magmatism and implications for early Archaean crustal growth. Journal of Petrology, 41, 1653-1671.

Smithies, R.H.; Champion, D.C. and Cassidy, K.F., (2003). Formation of Earth's early Archaean continental crust. Precambrian Research, 127, 89-101.

Stanistreet, I.G., McCarthy, T.S., Charlesworth, E.G., Myers, R., Armstrong, R.A., (1986). Pre-Transvaal wrench tectonics along the northern margin of the Witwatersrand Basin, South Africa. Tectonophysics, 131, 53-74.

Stanistreet, I.G., McCarthy, T.S., (1990). Middle Ventersdorp graben development north of Carletonville Goldfield and its relevance to the evolution of the Witwatersrand Basin. South African Journal of Geology, 93, 272-288.

Sun, S. S. and McDonough, W. F., (1989). Chemical and isotopic systematics of oceanic basalts: implications for mantle compositions and processes. In: A.D. Saunders and M.J. Norry. (Editors). Magmatism in the Ocean Basins. Geological Society of London, Special Publications, 42, 313-345.
Thomas, R. J., von Veh, M. W., McCourt, S., (1993). The tectonic evolution of southern Africa: an overview. Journal of African Earth Sciences, $16,5-24$.

Taylor, S.R., McLennan, S.M., (1981). The composition and evolution of the continental crust: rare earth element evidence from sedimentary rocks. Phil Transactions Royal Society of London A, 301, 381-399.

Twist, D., Harmer, R.E.J., (1987). Geochemistry of constrasting siliceous magmatic suites in the Bushveld Complex: Genetic aspects and implications for tectonic discrimination diagrams. Journal of Volcanology and Geothermal Research, 32, 83-98.

Viljoen, M.J., Viljoen, R.P. ,(1969). The geology and geochemistry of the Lower Ultramafic Unit of the Onverwacht Group and a proposed new classification of igneous rocks, Special Publication Geological Society South Africa, 2, 55-85.

Windley, B.F., (1995). The Evolving Continents, John Wiley and sons, Chichester. 526pp.

Wyllie, P.J., Wolf, M.B., van der Laan, S.R., (1997). Conditions for Formation of Tonalites and Trondhjemites: Magmatic sources and products. In: J.M. De Wit and L.D. Ashwal, (Editors.), Tectonic evolution of greenstone belts. Oxford University Press, 258-267.

Editorial editing J. Barton Jr. 


\section{Appendix 1 \\ Analytical methods}

Electron microprobe conditions

Mineral compositions were determined on carboncoated polished sections using the JEOL733 superprobe at the Council for Geoscience, Pretoria. Operating conditions were:

1. a) plagioclase $-15 \mathrm{kV}, 20 \mathrm{nA}$ beam current, and beam diameter of 2 to $3 \mu \mathrm{m}$;

2. b) amphibole $-15 \mathrm{kV}, 40 \mathrm{nA}$ beam current, beam diameter of 2 to $3 \mu \mathrm{m}$;

3. 2) counting time at the element peak position was ten seconds and five seconds at two symmetrical background positions;

4. 3) $\mathrm{Si}, \mathrm{Al}, \mathrm{Na}$ and $\mathrm{Mg}$ were analyzed with a TAP crystal and a gas flow detector, $\mathrm{Ti}$ and $\mathrm{Cr}$ with a PET crystal and xenon counter, Mn and Fe with a LiF crystal and xenon counter, and $\mathrm{Ca}$ and $\mathrm{K}$ with PET crystal and gas flow counter;

5. 4) An on-line Fortran program, supplied by JEOL (FZAFOC), utilizing the absorption correction of Philibert (1963) and Heinrich (1968), the atomic number correction of Duncumb and Reid (1968) and the fluorescence correction of Reed (1965), was used for the calculation of the final element concentrations;

6. 5) Estimation of $\mathrm{Fe}^{2+} / \mathrm{Fe}^{3+}$ content in oxide phases was done using the method of Droop (1987);

7. 6) Amphibole end-member classification was done using the program, which uses the amphibole classification scheme by Leake (1978).

\section{$X$-ray Fluorscence spectrometry}

Fresh unaltered rock samples ranging from 5 to $15 \mathrm{~kg}$ collected during fieldwork were crushed and powdered. Major element data were obtained from fusion disks using the Philips PW1480 X-ray fluorescence (XRF) spectrometer and trace-element data from pressed powder pellets using a Philips PW1400 XRF spectrometer, at the Council for Geoscience. The preparation of the fusion disks as well as the calibration method used for determination of major and trace elements are described by Cloete and Truter (2001).

\section{Inductively Coupled Plasma Mass Spectroscopy}

Selected trace elements and Rare-earth-elements data were obtained by Inductively Coupled Plasma Mass Spectroscopy (ICP-MS) at the Council for Geoscience. The details of the calibration and sample preparation are described by Jordaan, Maritz and Lehaha, (2005). Accuracy of the technique - average recovery (measured value/certified value * 100 , in \%) between 97 to $104 \%$ on $4 \mathrm{crm}$ 's included in batch of samples. Reproducibility of the method is between 10 to $13 \%$ relative standard deviation (RSD).

All analytical data were processed using the GRAPHER 3 software (2002).

\section{Modal analysis}

Modal point counting analysis on selected granitoid samples were done according to the method described by Hutchinson (1974). 
Copyright of South African Journal of Geology is the property of Geological Society of South Africa and its content may not be copied or emailed to multiple sites or posted to a listserv without the copyright holder's express written permission. However, users may print, download, or email articles for individual use. 